OPEN ACCESS

Edited by:

Celio Geraldo Freire-de-Lima, Universidade Federal do Rio de Janeiro, Brazil

Reviewed by:

Heloisa D'Avila Da Silva Bizarro, Universidade Federal de Juiz de Fora,

Brazil

Phileno Pinge-Filho,

State University of Londrina, Brazil

${ }^{*}$ Correspondence: Bellisa Freitas Barbosa bellisafb@ufu.br

Specialty section: This article was submitted to Infectious Diseases,

a section of the journal

Frontiers in Microbiology

Received: 03 December 2018 Accepted: 28 January 2019

Published: 12 February 2019

Citation:

Pereira ACA, Silva RJ, Franco PS, de Oliveira Gomes A, Souza G,

Milian ICB, Ribeiro M, Rosini AM, Guirelli PM, Ramos ELP, Mineo TWP, Mineo JR, Silva NM, Ferro EAV and Barbosa BF (2019) Cyclooxygenase

(COX)-2 Inhibitors Reduce

Toxoplasma gondii Infection

and Upregulate the Pro-inflammatory

Immune Response in Calomys callosus Rodents and Human

Monocyte Cell Line.

Front. Microbiol. 10:225.

doi: 10.3389/fmicb.2019.00225

\section{Cyclooxygenase (COX)-2 Inhibitors Reduce Toxoplasma gondii Infection and Upregulate the Pro-inflammatory Immune Response in Calomys callosus Rodents and Human Monocyte Cell Line}

\begin{abstract}
Ana Carolina Alcântara Pereira ${ }^{1}$, Rafaela José Silva ${ }^{1}$, Priscila Silva Franco ${ }^{1}$, Angelica de Oliveira Gomes², Guilherme Souza', Iliana Claudia Balga Milian', Mayara Ribeiro ${ }^{1}$, Alessandra Monteiro Rosini', Pâmela Mendonça Guirelli' Eliézer Lucas Pires Ramos 3 , Tiago Wilson Patriarca Mineo ${ }^{3}$, José Roberto Mineo Neide Maria Silva ${ }^{4}$, Eloisa Amália Vieira Ferro ${ }^{1}$ and Bellisa Freitas Barbosa ${ }^{1 *}$
\end{abstract}

${ }^{1}$ Laboratory of Immunophysiology of Reproduction, Institute of Biomedical Sciences, Universidade Federal de Uberlândia, Uberlândia, Brazil, ${ }^{2}$ Institute of Natural and Biological Sciences, Universidade Federal do Triângulo Mineiro, Uberaba, Brazil, ${ }^{3}$ Laboratory of Immunoparasitology, Institute of Biomedical Sciences, Universidade Federal de Uberlândia, Uberlândia, Brazil, ${ }^{4}$ Laboratory of Immunopathology, Institute of Biomedical Sciences, Universidade Federal de Uberlândia, Uberlândia, Brazil

Toxoplasma gondii is able to infect a wide range of vertebrates, including humans. Studies show that cyclooxygenase-2 (COX-2) is a modulator of immune response in multiple types of infection, such as Trypanosoma cruzi. However, the role of COX-2 during T. gondii infection is still unclear. The aim of this study was to investigate the role of COX-2 during infection by moderately or highly virulent strains of $T$. gondii in Calomys callosus rodents and human THP-1 cells. C. callosus were infected with 50 cysts of T. gondii (ME49), treated with COX-2 inhibitors (meloxicam or celecoxib) and evaluated to check body weight and morbidity. After 40 days, brain and serum were collected for detection of $T$. gondii by real-time PCR and immunohistochemistry or cytokines by CBA. Furthermore, peritoneal macrophages or THP-1 cells, infected with $\mathrm{RH}$ strain or uninfected, were treated with meloxicam or celecoxib to evaluate the parasite proliferation by colorimetric assay and cytokine production by ELISA. Finally, in order to verify the role of prostaglandin $E_{2}$ in COX-2 mechanism, THP-1 cells were infected, treated with meloxicam or celecoxib plus $\mathrm{PGE}_{2}$, and analyzed to parasite proliferation and cytokine production. The data showed that body weight and morbidity of the animals changed after infection by T. gondii, under both treatments. Immunohistochemistry and real-time PCR showed a reduction of $T$. gondii in brains of animals treated with both COX-2 inhibitors. Additionally, it was observed that both COX-2 inhibitors controlled the T. gondii proliferation in peritoneal macrophages and THP-1 cells, and the treatment with $\mathrm{PGE}_{2}$ restored the parasite growth in THP-1 cells blocked to COX-2. In the serum of Calomys, upregulation of pro-inflammatory 
cytokines was detected, while the supernatants of peritoneal macrophages and THP-1 cells demonstrated significant production of TNF and nitrite, or TNF, nitrite and MIF, respectively, under both COX-2 inhibitors. Finally, $\mathrm{PGE}_{2}$ treatment in THP-1 cells triggered downmodulation of pro-inflammatory mediators and upregulation of IL-8 and IL-10. Thus, COX-2 is an immune mediator involved in the susceptibility to $T$. gondii regardless of strain or cell types, since inhibition of this enzyme induced control of infection by upregulating important pro-inflammatory mediators against Toxoplasma.

Keywords: Toxoplasma gondii, cyclooxygenase-2, Calomys callosus, THP-1 cells, prostaglandin $\mathrm{E}_{2}$, immune response

\section{INTRODUCTION}

Toxoplasmosis is an infectious disease caused by the protozoan parasite Toxoplasma gondii, which can invade and replicate in any type of nucleated cell, including macrophages, cells from the nervous system and muscle tissue (Montoya and Liesenfeld, 2004; Dubey, 2010; Robert-Gangneux and Dardé, 2012). Actually, around one-third of the world's population is infected with T. gondii, becoming this parasite one of the best adapted to infect humans (Laliberté and Carruthers, 2008; Dubey, 2010). When the infection is established in immunocompromised patients or during pregnancy, severe manifestations can be observed, especially in newborns or in children congenitally infected, such as retinochoroiditis, encephalitis, and miscarriage (Dubey et al., 2012). A recent study showed that seroprevalence in pregnant women in Brazil is $36-92 \%$, so characterizing a serious public health problem (Foroutan-Rad et al., 2016). Furthermore, programs of prevention of congenital toxoplasmosis in pregnant women can be only found in a limited number of countries. A French screening program established since 1992 requires monthly testes in pregnant women until delivery, in order to reduce significantly the rate of congenital transmission (Peyron et al., 2017). Thus, new strategies to prevent or treat the toxoplasmosis are welcome, in order to minimize the public health problem and to improve the quality of life of children and immunocompromised individuals infected by the parasite.

The immune response to $T$. gondii infection is predominantly pro-inflammatory (Lang et al., 2007). During infection, cells from innate immunity, such as macrophages, neutrophils, and dendritic cells recognize the parasite by pathogen-associated molecular patterns (Hou et al., 2011; Koblansky et al., 2013; Gorfu et al., 2014) and produce high levels of pro-inflammatory cytokines, such as interleukin (IL)-12, which activates $\mathrm{CD} 4^{+} \mathrm{T}$ lymphocytes to produce interferon (IFN)- $\gamma$, the major cytokine involved in control of T. gondii (Gazzinelli et al., 1994; Kemp et al., 2013; Koblansky et al., 2013; Behnke et al., 2017). In parallel to IFN- $\gamma$, other pro-inflammatory cytokines, such as IL-6, tumoral necrosis factor (TNF), IL-17A, IL-2 and macrophage migration inhibitory factor (MIF) also participate significantly in the immunity against $T$. gondii (Kelly et al., 2005; Castro et al., 2013; Barbosa et al., 2014, 2015; Gomes et al., 2018). Our previous studies demonstrated that human trophoblast cells controlled T. gondii intracellular proliferation in a MIF-dose-dependent manner, since only high concentrations of recombinant MIF
(rMIF) were able to reduce the parasite growth. On the other hand, low concentrations of rMIF triggered significant production of prostaglandin $\mathrm{E}_{2}\left(\mathrm{PGE}_{2}\right)$ and, consequently, increased susceptibility to T. gondii in human trophoblast cells, showing the potential effect of $\mathrm{PGE}_{2}$ to favor parasite replication (Barbosa et al., 2014). Thus, the parasite can use some molecules from the host, such as $\mathrm{PGE}_{2}$, to evade the immune response and to establish definitely into the host cells (Barbosa et al., 2014).

Prostaglandins are lipid mediators involved in many activities, including inflammatory and immunological functions, since the participation of prostaglandins in the cellular activation and maturation, and cytokine production in cells from innate immunity as macrophages and dendritic cells, has been confirmed (Nagamatsu and Schust, 2010; Kalinski, 2012). Prostaglandins, especially $\mathrm{PGE}_{2}$, are synthesized when phospholipase $\mathrm{A}_{2}$ promotes the release of arachidonic acid from the plasmatic membrane (Pawlowski et al., 1983; Agard et al., 2013). Subsequently, the arachidonic acid is converted into prostaglandins by enzymes called cyclooxygenases (COXs). There are at least two isoforms of COX: COX-1, constitutively expressed in all cell types, and COX-2, which is induced by inflammatory mediators, mainly cytokines (Batlouni, 2010; Agard et al., 2013; Sharma et al., 2017; Martínez-Colón and Moore, 2018).

Many studies demonstrate the role of COX-2 and $\mathrm{PGE}_{2}$ during infection triggered by Trypanosoma cruzi, and these mediators are shown to be essential to survival of this pathogen in the host cells, inducing replication and dissemination of the pathogen, as well as downmodulation of immune response. COX-2 expression is significantly increased when infection by $T$. cruzi is present, confirming that this parasite is a potent inductor of COX-2 (Moraes et al., 2015). Mice infected with T. cruzi showed reduced parasitism in blood and cardiac muscle when treated with COX-2 inhibitors (meloxicam, etoricoxib, sodium salicylate, aspirin, or celecoxib) (Michelin et al., 2005; Abdalla et al., 2008; Tatakihara et al., 2008). In addition, COX inhibitors diminished the internalization of T. cruzi in mice peritoneal macrophages and, at the same time, upregulated IL-1 $\beta$ and nitrite, demonstrating the potential role of COX in favoring the infection by T. cruzi by downmodulating pro-inflammatory mediators (Malvezi et al., 2014). Thus, the roles of COX-2 and $\mathrm{PGE}_{2}$ during infections triggered by $T$. cruzi are already widely discussed in the literature, since both are mentioned as inductors of the immunosuppression observed during the acute phase of 
Chagas disease, favoring the persistence of the parasite into host cells (Pinge-Filho et al., 1999).

However, the role of COX-2 during infections triggered by T. gondii is still unclear. Mota et al. (2014) observed an increase of lipid droplets in mice peritoneal macrophages infected with T. gondii, and it was associated with high levels of $\mathrm{PGE}_{2}$ and low levels of nitrite. Furthermore, primary cultures of skeletal muscle cells infected with T. gondii also presented higher numbers of lipid droplets and increased COX-2 and $\mathrm{PGE}_{2}$ expression (Gomes et al., 2014), but there are no studies demonstrating an association between COX-2 and susceptibility to $T$. gondii infection with different strains of this parasite. In this sense, the aim of the present study was to investigate the role of COX-2 during infection by moderately or highly virulent strains of $T$. gondii in Calomys callosus, a rodent of the family Cricetidae, widely distributed in Central Brazil. Our research group has been used C. callosus widely as an experimental model for toxoplasmosis studies (Barbosa et al., 2007, 2012; Costa et al., 2009; Franco et al., 2014, 2015), since this rodent has been described as a reservoir for various infectious agents (Borges et al., 1992; Favoreto-Júnior et al., 1998). Also, we verified the role of COX-2 during infection by T. gondii in human monocyte cell line (THP1 cells), in order to compare the COX-2 activity between rodent cells and human cells.

\section{MATERIALS AND METHODS}

\section{Animals}

Calomys callosus (8 to 10 weeks) were kept in a room with adequate temperature $\left(25 \pm 2^{\circ} \mathrm{C}\right)$ and luminosity (12-h light, 12-h dark), under specific pathogen-free conditions, and free access to food and water. The colony was maintained in the Animal Experimentation Center of the Institute of Biomedical Sciences, Universidade Federal de Uberlândia, Uberlândia, Brazil. This study was carried out in accordance with the recommendations of institutional guidelines for animal ethics, Comissão de Ética na Utilização de Animais (CEUA-UFU). All procedures were approved and conducted according to institutional guidelines for animal ethics (Approval No. 232/13).

\section{Cell Culture}

Human monocyte (THP-1) and human choriocarcinoma (BeWo) cell lines were obtained from American Type Culture Collection (ATCC, Manassas, VA, United States). Both cells were cultured in culture flasks of $75 \mathrm{~cm}^{2}$ containing Roswell Park Memorial Institute (RPMI) 1640 medium (Cultilab, Campinas, Brazil) with penicillin $(100 \mathrm{U} / \mathrm{mL})$ and streptomycin (100 $\mu \mathrm{g} / \mathrm{mL}$ ) antibiotics (both from Sigma Chemical Co., St. Louis, MO, United States), and 10\% heat-inactivated fetal bovine serum (FBS) (Cultilab). The cells were maintained in a humidified incubator at $37^{\circ} \mathrm{C}$ and $5 \% \mathrm{CO}_{2}$ (Castro et al., 2013; Barbosa et al., 2015).

\section{Parasite Strains}

The T. gondii ME49 strain (moderately virulent - type II) was obtained from previously infected $C$. callosus males
(Barbosa et al., 2007). Briefly, the males were euthanized and the brains were collected. Next, the brains were washed in sterile $0.01 \mathrm{M}$ phosphate-buffered saline (PBS, pH 7.2) to remove the excess blood, fragmented with a syringe and a needle $(25 \times 7$ gauge $)$ for $5 \mathrm{~min}$ at least, and again washed with PBS by centrifugation at $1000 \times g$ for $10 \mathrm{~min}$. Finally, $20 \mu \mathrm{L}$ homogenized brains were placed in glass slides under coverslip and the number of cysts were counted with light microscopy (Barbosa et al., 2007).

Toxoplasma gondii tachyzoites of the $2 \mathrm{~F} 1$ clone were provided from Dr. Vern Carruthers (Medical School of Michigan University, Ann Arbor, MI, United States). This clone is derived from RH parasites, a highly virulent strain from type I. These tachyzoites constitutively express cytoplasmic beta-galactosidase, which enable a colorimetric assay to measure the parasites in cells or tissues (Castro et al., 2013; Barbosa et al., 2015). The parasites were propagated in vitro in BeWo cells cultured in RPMI 1640 medium containing the penicillin and streptomycin antibiotics, as above described, and $2 \%$ FBS.

\section{Treatment of C. callosus Females With COX-2 Inhibitors}

In the first step of the experiments, we investigated the role of COX-2 inhibitors during the chronic phase of T. gondii infection.

For this purpose, $C$. callosus females $(n=24)$ were analyzed for body weight and morbidity score, and immediately infected with 50 cysts of T. gondii (ME49 strain) via oral route (day 1). Twentyfour hours later (day 2), the females were divided into three groups with eight animals, as follows: females infected and treated with water (group 1 - control); females infected and treated with a preferential COX-2 inhibitor, meloxicam (Eurofarma Laboratórios, São Paulo, Brazil) at $0.5 \mathrm{mg} / \mathrm{kg}$ (Abdalla et al., 2008) (group 2); and females infected and treated with a specific COX-2 inhibitor, celecoxib (Pfizer Pharmaceuticals LLC, Guarulhos, Brazil) at $5 \mathrm{mg} / \mathrm{kg}$ (Short et al., 2013) (group 3). All the groups received the treatments daily, diluted in filtered drinking water, via oral route, for 40 consecutive days. In these 40 days, the animals were monitored daily to observe any signal of suffering and, in positive case, the euthanasia would be carried out immediately. The body weight change and score morbidity were evaluated every $72 \mathrm{~h}$. Morbidity was assessed based on the clinical parameters as previously described, with minor modifications: sleek/glossy coat, bright and active (score 0 ); hunched, starry stiff coat (score 1); and reluctance to move (score 2) (Bartley et al., 2006; Franco et al., 2014).

After 40 days of treatment and infection (day 42), the females were anesthetized, the blood was collected and serum stored at $-80^{\circ} \mathrm{C}$ for posterior cytokine and nitrite measurements. Next, the females were euthanized and the brain was collected for further detection of tissue parasitism by quantitative real-time PCR and immunohistochemistry, as well as Western blotting for COX-2 expression. Uninfected and untreated females $(n=8)$ were used in the experiments only to obtain serum and brain in order to detect cytokine and nitrite or COX-2 expression to compare with infected and untreated animals. 


\section{DNA Extraction and Quantitative Real-Time PCR (qRT-PCR)}

The T. gondii DNA was quantified by RT-PCR and it was carried out according to our previous study (Franco et al., 2014), with minor modifications. The brains from C. callosus were frozen in liquid nitrogen and immediately processed to extract total DNA using the Promega Wizard Genomic DNA Purification kit following the manufacturer's instructions (Promega Co., Madison, WI, United States). DNA for analyze was extracted from $20 \mathrm{mg}$ of the tissues. The quantification was performed using UV spectrophotometry (ND1000 Spectrophotometer; NanoDrop Technologies, Wilmington, DE, United States). The samples were prepared with Promega Master Mix Kit Go Taq ${ }^{\circledR}$ Quantitative Real-Time PCR, and the StepOnePlus ${ }^{\circledR}$ Real-Time PCR System (Applied Biosystems, Carlsbad, CA, United States) was used to thermal profile of the reaction stages. The primer pairs used were (Tg529 forward, 5'-GCTCCTCCAGCCGTCTTC-3'; and Tg529 reverse, $5^{\prime}$-CCTCACCCTCGCCTTCAT-3') (Exxtend, Campinas, Brazil), amplifying a region with 529 base pairs (bp), as described by Homan et al. (2000). Positive control of the reaction was a suspension of RH strain tachyzoites $\left(10^{4}\right.$ tachyzoites $\left./ \mathrm{mL}\right)$, and ultrapure water was used as negative control. The standard curve and samples were carried out with 100 and 200 ng of DNA targets, respectively.

\section{Immunohistochemistry for T. gondii Detection}

To verify the presence of T. gondii cysts in brains of C. callosus, the samples were submitted to immunohistochemistry assay. For this purpose, the brains were fixed in $10 \%$ formalin in PBS for $24 \mathrm{~h}$, embedded in paraffin and the glass slides containing sections of $4 \mu \mathrm{m}$ obtained in microtome were treated for 5 min with citric acid ( $\mathrm{pH}$ 6.0) for antigenic recovery. Next, $5 \%$ acetic acid solution was added on the sections for $8 \mathrm{~min}$ to avoid detection of endogenous phosphatase, and posteriorly the sections were treated with $2.5 \%$ goat serum for $45 \mathrm{~min}$ at $37^{\circ} \mathrm{C}$ to inhibit recognition of non-specific sites. After, the sections were incubated with 1:100 primary antibody (previously infected C. callosus serum) during $12 \mathrm{~h}$ at $4^{\circ} \mathrm{C}$, washed in Tris-buffered saline solution (TBS, pH 7.4) to remove the excess of antibodies, and treated with 1:600 secondary antibody (biotinylated goatanti mouse IgG, Jackson Immuno Research Laboratories, West Grove, PA, United States) for $1 \mathrm{~h}$ at $37^{\circ} \mathrm{C}$. Finally, the detection of parasites was developed for $10 \mathrm{~min}$ with fast red naphthol (Sigma) at room temperature, and the brains counterstained with Harris's hematoxylin were visualized under light microscope (BX40, Olympus, Tokyo, Japan) (Gomes et al., 2011; Castro-Filice et al., 2014).

\section{Culture of Peritoneal Macrophages}

Peritoneal macrophages were obtained from 10 to 12-week old female C. callosus, according to Rodrigues et al. (2012) with minor modifications. Briefly, 3 days before collecting peritoneal macrophages, females $(n=6)$ were stimulated with $1 \mathrm{~mL}$ of $4 \%$ thioglycollate medium (BD Bioscience, San Jose,
CA, United States) to induce recruitment of macrophages. Next, the animals were euthanized and the peritoneum washed with $5 \mathrm{~mL}$ ice cold RPMI 1640 medium supplemented with penicillin $(100 \mathrm{U} / \mathrm{mL})$, streptomycin $(100 \mu \mathrm{g} / \mathrm{mL})$, and $10 \%$ FBS. The cells were harvested, centrifuged at $400 \times g$ for $5 \mathrm{~min}$, adjusted to $1 \times 10^{5}$ cells $/ 200 \mu \mathrm{L}$ in RPMI supplemented with penicillin $(100 \mathrm{U} / \mathrm{mL})$, streptomycin $(100 \mu \mathrm{g} / \mathrm{mL})$ and $10 \%$ FBS, seeded in 96-well plates (Corning Corporation, Cambridge, MA, United States) and incubated in a humidified incubator at $37^{\circ} \mathrm{C}$ and $5 \% \mathrm{CO}_{2}$. After $24 \mathrm{~h}$, the supernatants were collected to remove the non-adherent cells. The adherent cells were considered peritoneal macrophages (Rodrigues et al., 2012).

\section{Viability Assay in Peritoneal Macrophages Treated With cOX-2 Inhibitors}

The peritoneal macrophages $\left(1 \times 10^{5}\right.$ cells/200 $\mu \mathrm{L}$ in 96 well plates) were treated with increasing concentrations of meloxicam or celecoxib $(1,5,10,250,500$, and $1000 \mu \mathrm{g} / \mathrm{mL})$ in RPMI supplemented with penicillin, streptomycin and $10 \%$ FBS for $24 \mathrm{~h}$ in a humidified incubator at $37^{\circ} \mathrm{C}$ and $5 \%$ $\mathrm{CO}_{2}$. As control, the cells were treated with medium only. For viability assay, the cells were incubated for $4 \mathrm{~h}$ in RPMI medium containing 3-(4,5-Dimethyl-2-thiazolyl)-2,5-diphenyl$2 \mathrm{H}$-tetrazolium bromide (MTT) at $37^{\circ} \mathrm{C}$ and $5 \% \mathrm{CO}_{2}$. Next, the formazan crystals produced by viable cells were homogenized for $30 \mathrm{~min}$ in $10 \%$ sodium dodecyl sulfate (SDS, Sigma) and $50 \% \mathrm{~N}, \mathrm{~N}$-dimethyl formamide (Sigma) (Mosmann, 1983), and the optical densities measured at $570 \mathrm{~nm}$ (Titertek Multiskan Plus, Flow Laboratories, McLean, VA, United States). The optical densities of all experimental conditions with meloxicam or celecoxib were calculated to percentage in relation to untreated cells, considered as $100 \%$ viability. Two independent experiments with six replicates were performed.

\section{T. gondii Intracellular Proliferation in Peritoneal Macrophages Treated With COX-2 Inhibitors}

After verifying the toxicity of meloxicam or celecoxib by MTT, we chose the non-toxic concentrations of both inhibitors to analyze the $T$. gondii intracellular proliferation in peritoneal macrophages. For this purpose, peritoneal macrophages $\left(1 \times 10^{5}\right.$ cells/200 $\mu \mathrm{L}$ in 96-well plates) were infected with $T$. gondii tachyzoites (2F1 clone, $\mathrm{RH}$ strain) in a proportion of three parasites per cell $(3: 1)$, and after $3 \mathrm{~h}$ of culture, the cells were treated with $1,5,10,250,500$, or $1000 \mu \mathrm{g} / \mathrm{mL}$ meloxicam or 1 , 5 , or $10 \mu \mathrm{g} / \mathrm{mL}$ celecoxib in RPMI supplemented with penicillin, streptomycin and 10\% FBS for an additional $24 \mathrm{~h}$. As controls, macrophages were treated and not infected, infected and not treated, or not infected and not treated. Then, the supernatants were collected and stored at $-80^{\circ} \mathrm{C}$ for posterior cytokine and nitrite measures, while the cells were submitted to $T$. gondii intracellular proliferation assay by $\beta$-galactosidase colorimetric reaction as previously described (Barbosa et al., 2015). T. gondii intracellular proliferation was presented as number of tachyzoites and calculated in reference to a standard curve obtained from free 
2F1 parasites (detection limit: $15.6 \times 10^{3}$ tachyzoites) (Barbosa et al., 2015). Three independent experiments with six replicates were performed.

\section{T. gondii Intracellular Proliferation in THP-1 Cells Treated With COX-2 Inhibitors and/or $\mathrm{PGE}_{2}$}

In order to verify the COX-2 intracellular mechanism in human cells, besides tissue and macrophage of rodents, THP-1 cells $\left(3 \times 10^{4}\right.$ cells $/ 200 \mu \mathrm{L}$ in 96 -well plates $)$ were infected with $2 \mathrm{~F} 1 \mathrm{~T}$. gondii tachyzoites $(3: 1)$ and treated with $250 \mu \mathrm{g} / \mathrm{mL}$ meloxicam or $10 \mu \mathrm{g} / \mathrm{mL}$ celecoxib, and incubated in the same culture conditions, as above described, for an additional $24 \mathrm{~h}$.

After, to evaluate the role of $\mathrm{PGE}_{2}$ and association between COX-2 and $\mathrm{PGE}_{2}$ during infection with T. gondii, THP-1 cells $\left(3 \times 10^{4}\right.$ cells $/ 200 \mu \mathrm{L}$ in 96-well plates) were infected with $2 \mathrm{~F} 1$ tachyzoites (3:1), treated with several concentrations of $\mathrm{PGE}_{2}$ (Cayman Chemical, Ann Arbor, MI, United States) (0.015, 0.150, $8,20,40$, or $80 \mathrm{ng} / \mathrm{mL}$ ) according to our previous study (Barbosa et al., 2014), and maintained in culture for additional $24 \mathrm{~h}$. In a second step, THP- 1 cells $\left(3 \times 10^{4}\right.$ cells $/ 200 \mu \mathrm{L}$ in 96 -well plates $)$ were infected (3:1), and treated with meloxicam $(250 \mu \mathrm{g} / \mathrm{mL})$ or celecoxib $(10 \mu \mathrm{g} / \mathrm{mL})$ plus 0.150 or $80 \mathrm{ng} / \mathrm{mL} \mathrm{PGE}_{2}$ for $24 \mathrm{~h}$. As controls, THP-1 cells were treated and not infected, infected and not treated, or not infected and not treated. Also, THP-1 cells were infected and treated with $0.022 \%$ DMSO, the diluent of $\mathrm{PGE}_{2}$, to exclude any effect of DMSO in the parasitism or cytokine/nitrite production.

Supernatants were collected and stored at $-80^{\circ} \mathrm{C}$ for posterior cytokine and nitrite measures, while the cells were submitted to $T$. gondii intracellular proliferation assay by $\beta$-galactosidase colorimetric reaction as previously described (Barbosa et al., 2015). Two independent experiments with eight replicates were performed.

\section{Western Blotting}

In order to confirm the inhibition or reduction of COX-2 expression in cells (peritoneal macrophages or THP-1 cells) and brains of females treated with meloxicam or celecoxib, we performed Western blotting to detect COX-2.

For this purpose, peritoneal macrophages or THP-1 cells $\left(1 \times 10^{6}\right.$ cells $/ 2000 \mu \mathrm{L}$ in 6 -well plates) were infected (3:1) and treated with meloxicam $(250,500$, and $1000 \mu \mathrm{g} / \mathrm{mL}$ for peritoneal macrophages, or $250 \mu \mathrm{g} / \mathrm{mL}$ for THP-1) or celecoxib $(1,5$, or $10 \mu \mathrm{g} / \mathrm{mL}$ for peritoneal macrophages, or $10 \mu \mathrm{g} / \mathrm{mL}$ for THP-1) in RPMI medium containing 10\% FBS during $24 \mathrm{~h}$. As positive control for COX-2 expression, peritoneal macrophages were not infected and only treated with $1 \mu \mathrm{g} / \mathrm{mL}$ LPS (InvivoGen, Toulouse, France) for $24 \mathrm{~h}$. After, the cells were collected, lysed in ice RIPA buffer [ $50 \mathrm{mM}$ Tris- $\mathrm{HCl}, 150 \mathrm{mM} \mathrm{NaCl}, 1 \%$ Triton $\mathrm{X}-100,1 \%(\mathrm{w} / \mathrm{v})$ sodium deoxycholate, and $0.1 \%(\mathrm{w} / \mathrm{v})$ sodium dodecyl sulfate (SDS), $\mathrm{pH}$ 7.5] supplemented with protease inhibitor cocktail (Complete, Roche Diagnostic, Mannheim, Germany), $1 \mathrm{mM}$ sodium orthovanadate $\left(\mathrm{Na}_{3} \mathrm{VO}_{4}\right)$ and sodium fluoride $(\mathrm{NaF})$ (Sigma), and submitted to three freeze-thaw cycles for protein extraction. The total protein was centrifuged $\left(21,000 \times g, 10 \mathrm{~min}, 4^{\circ} \mathrm{C}\right)$, measured by Bradford assay (Bradford, 1976), and submitted to Western blotting for COX-2 detection. In parallel, brains (fragments) of C. callosus females from all experimental groups were lysed as above described and submitted to Western blotting for COX-2.

Electrophoresis in polyacrylamide gel (SDS-PAGE) was performed in $100 \mu \mathrm{g}$ total protein. Next, the proteins were transferred to polyvinylidene fluoride (PVDF) membranes (Thermo Scientific, Rockford, IL, United States), blocked with $4 \%$ skimmed milk in Tris-buffered saline solution (TBS: $25 \mathrm{mM}$ TRIS and $0.15 \mathrm{M} \mathrm{NaCl}, \mathrm{pH}$ 7.4) for $1 \mathrm{~h}$, and incubated overnight with goat polyclonal anti-COX-2 (1:100, R\&D Systems, Minneapolis, MN, United States) or mouse monoclonal antibeta-actin (1:1000, Santa Cruz Biotechnology, Santa Cruz, CA, United States) in TBS. Then, membranes were incubated with respective HRP-secondary antibodies (1:3000, Jackson ImmunoResearch Laboratories) in TBS with $2 \%$ skimmed milk for $2 \mathrm{~h}$, washed and revealed by chemiluminescence kit (Thermo Scientific) in ChemiDoc MP Imaging System (BIORAD Laboratories, Inc., Hercules, CA, United States).

\section{Measurement of Cytokines and Nitrite}

The serums of C. callosus from three experimental groups were used for the detection of Th1, Th2, and Th17 cytokines by cytometric bead array (CBA). Mouse cytokines (IL-2, IL-4, IL-6, IFN- $\gamma$, TNF, IL-17A, and IL-10) were measured in serums using the Th1/Th2/Th17 kit according to the BD Bioscience instructions. The level of cytokines was evaluated under FACSCalibur flow cytometry (BD Company, San Diego, CA, United States), processed with BD Cell Quest and CBA softwares, and the data were presented as mean fluorescence intensity (MFI) according to a standard curve of each cytokine (Franco et al., 2011; Barbosa et al., 2015).

In addition, the supernatants of cell cultures were used to measure IL-6, TNF, IFN- $\gamma$, IL-17A, and IL-10 cytokines in peritoneal macrophages, or IL-6, TNF, IFN- $\gamma$, IL-10, TGF- $\beta 1$, MIF, and IL-8 cytokines in THP-1 cells, by sandwich ELISA according to the $\mathrm{BD}$ Bioscience or R\&D Systems instructions. The data were expressed in $\mathrm{pg} / \mathrm{mL}$ according to a standard curve of each cytokine.

Both serums and supernatants were used to measure nitrite by the Griess method (Green et al., 1982). Briefly, serum and supernatant were added to 96-well plates, incubated with Griess reagent ( $1 \%$ sulfanilamide dihydrochloride and $0.1 \%$ naphthylenediamide dihydrochloride in $2.5 \% \mathrm{H}_{3} \mathrm{PO}_{4}$ ) for 10-20 $\mathrm{min}$, and the absorbance was read in a plate reader (Titertek Multiskan Plus) at $570 \mathrm{~nm}$. The nitrite concentration was determined with reference to a standard curve of sodium nitrite $(\mu \mathrm{M} / \mathrm{mL})$.

\section{Statistical Analysis}

Statistical analysis between different experimental conditions were verified by Mann-Whitney test or Bonferroni multiple comparison (one-way or two-way ANOVA) using GraphPad Prisma version 5.0 (GraphPad Software, Inc., San Diego, CA, United States). $P<0.05$ was considered as significant difference. 


\section{RESULTS}

\section{T. gondii Infection in C. callosus Induced Body Weight Change and Moderate Clinical Signs, Regardless of COX-2 Inhibitor Treatment}

In a first stage, we performed experiments during the chronic phase of infection. Body weight change and morbidity scores were verified every $72 \mathrm{~h}$ in C. callosus females infected with T. gondii (ME49 strain) and treated with COX-2 inhibitors (meloxicam or celecoxib) for 40 consecutive days. It is important to emphasize that $C$. callosus has a mean body weight around $40 \mathrm{~g}, \mathrm{ME} 49$ strain does not cause severe disease in these animals, and Calomys are widely used as toxoplasmosis model study (Ferro et al., 2002; Barbosa et al., 2007, 2012; Franco et al., 2014, 2015). The mortality rate of these animals is generally very low after $T$. gondii infection with moderately virulent strains, which enable to monitoring for many days. Thus, no animal from the experimental conditions tested succumbed to infection. In addition, no signal of severe suffering was observed in animals, then euthanasia was not performed before 40 days of infection/treatment as an endpoint strategy.

In general, changes in body weight and moderate clinical signs were induced by $T$. gondii in C. callosus, regardless of COX-2 inhibitor treatment (Figure 1).

All the COX-2 inhibitors, celecoxib $(P<0.001)$ and meloxicam $(P<0.001)$, induced significant body weight loss from day 3 post-infection (p.i.) to 39 p.i. in comparison to untreated females (control). It means that significant body weight loss was detected during all days evaluated in animals treated with meloxicam or celecoxib $(P<0.001)$, regardless of time of infection (Figure 1A). In addition, celecoxib-treated females lost more weight than meloxicam-treated females until the day 9 p.i. $(P<0.0001)$ (Figure 1A). However, from day 18 p.i. onwards, meloxicam-treated females started to lose weight more significantly compared to celecoxib-treated females $(P<0.0001)$ (Figure 1A).

Females treated with celecoxib were the first group to present clinical signs, showing increase of morbidity score at 6 days p.i. $(P<0.0001)$, since the animals started to present slight hunched, starry stiff coat (Figure 1B). On the other hand, from day 9 to 27 p.i., except at days 12 and 15, untreated females (control) started to present more significant clinical signs in relation to animals treated with COX-2 inhibitors $(P<0.0001)$, showing increased hunched, starry stiff coat and, at the same time, the females started to present moderately slower locomotion and reactions (Figure 1B). At 6, 9, 12, and 30 days p.i., morbidity score was higher in females treated with celecoxib (progressive increase of hunched, starry stiff coat and lower ability to move) in comparison to meloxicam-treated females $(P<0.0001)$ (Figure 1B). However, at 24 and 27 days p.i., females treated with meloxicam demonstrated higher morbidity score (hunched, starry stiff coat and lower ability to move) compared to celecoxib-treated females $(P<0.0001)$ (Figure 1B). From days 33 to 39 p.i., all the animals demonstrated similar morbidity score (increased hunched, starry stiff coat and lower ability to move) (Figure 1B).

\section{COX-2 Inhibitors Reduced Significantly the Tissue Parasitism in C. callosus Infected With T. gondii ME49 Strain}

After verifying the clinical parameters, we investigated the parasitism in brains of infected females treated or untreated with COX-2 inhibitors for 40 consecutive days (Figure 2).

Females treated with meloxicam or celecoxib showed lower parasite burdens in the brain in comparison to untreated and infected animals (control) $(P=0.0380)$ (Figure 2A). In order to confirm the reduction of COX-2 expression in these C. callosus females treated with COX-2 inhibitors, Western blotting was performed. As results, brains of uninfected and untreated females presented basal levels of COX-2. In the presence of $T$. gondii infection, untreated animals showed upregulation of COX-2, but when females were treated with meloxicam or celecoxib, a reduction of COX-2 in tissue brain was detected when compared to untreated and infected females (Figure 2B). In addition, we quantified the number of cystlike structures per brain tissue section (around 40 fields per section) using immunohistochemistry. It was verified a lower number of cyst-like structures in brains of females treated with meloxicam (mean of 18 structures) or celecoxib (mean of 15 structures) if compared to untreated females (mean of 37 structures) (data not shown). Representative photomicrographs of immunohistochemistry showing the presence of $T$. gondii in the brain, where it is possible to observe a reduced number of cyst-like structures (arrowed) in animals treated with meloxicam (Figure 2D) or celecoxib (Figure 2E) compared to untreated animals (Figure 2C).

Thus, it is possible to conclude that COX-2 is an important mediator during the chronic phase of $T$. gondii infection.

\section{COX-2 Inhibitors Upregulated Pro-inflammatory Cytokines in C. callosus Infected With T. gondii ME49 Strain}

After evaluating the parasite burden in tissues of infected C. callosus, we verified the cytokine levels in serum from those infected animals treated or untreated with COX-2 inhibitors for 40 consecutive days (Figure 3 ).

Untreated and infected females (control) showed production of all cytokines measured (Figures 3A-G). However, females treated with meloxicam or celecoxib demonstrated upregulation of IFN- $\gamma(P=0.049)$, IL-17A $(P=0.0115)$, TNF $(P=0.0289)$, and IL-6 $(P=0.0321)$, when compared to untreated animals (Figures 3A-D). No significant differences between untreated and treated females were detected on IL-10, IL-2 or IL-4 levels (Figures 3E-G). The nitrite production was undetected in all conditions, and untreated/uninfected females showed undetected levels of cytokines (data not shown). 

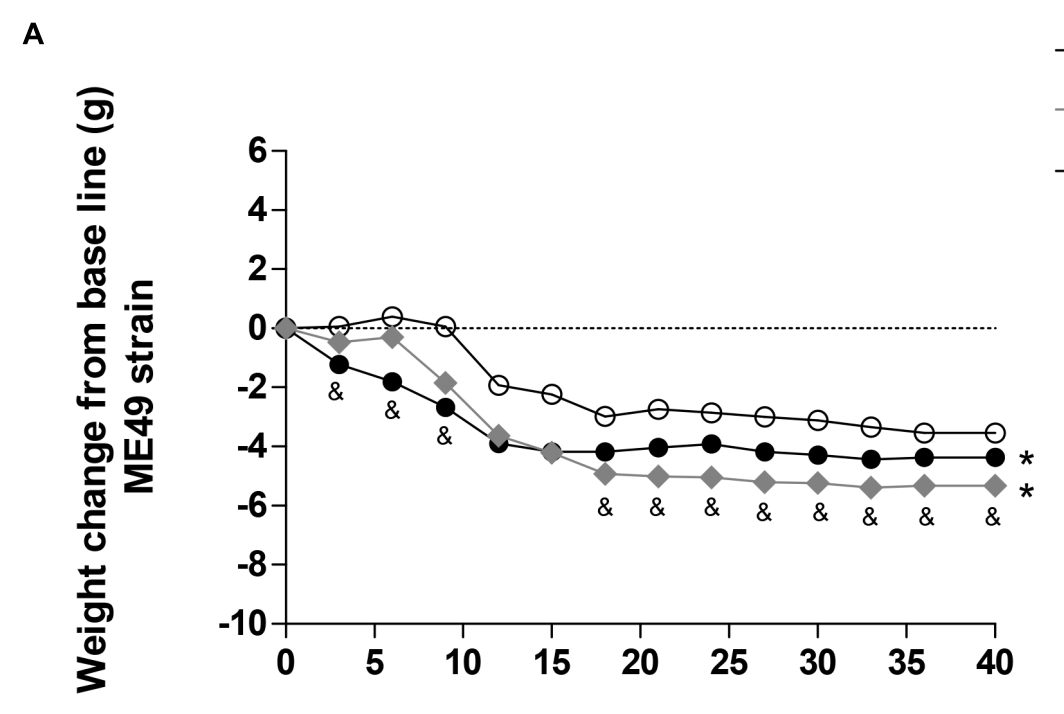

$\checkmark$ control

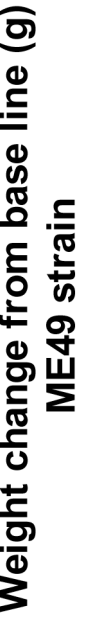

Days post-infection

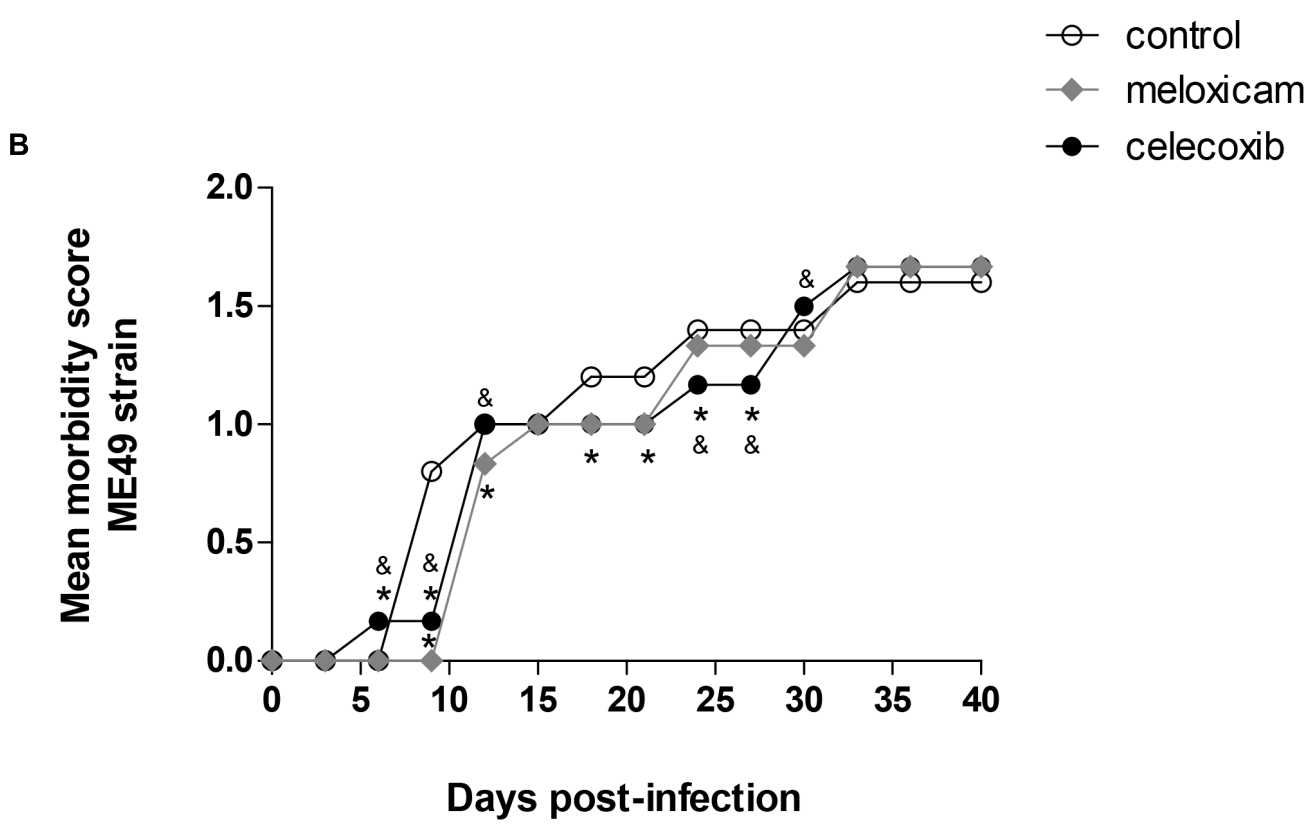

FIGURE 1 | Body weight change and score morbidity. Calomys callosus females were infected orally with 50 cysts of Toxoplasma gondii (ME49 strain), treated or untreated with meloxicam $(0.5 \mathrm{mg} / \mathrm{kg})$ or celecoxib $(5 \mathrm{mg} / \mathrm{kg})$ daily and monitored for body-weight change (A) and morbidity score (B) for 40 days. Dotted lines represent the absence of body-weight change (A). Differences between groups were verified by Mann-Whitney test. Significant differences from day 3 post-infection (p.i.) to 39 p.i. in relation to untreated/infected animals (control) $\left(^{*} P<0.05\right)$, and celecoxib/infected animals $\left({ }^{\&} P<0.05\right)$.

\section{COX-2 Inhibitors Reduced Significantly} the T. gondii Intracellular Proliferation in Peritoneal Macrophages Infected With

\section{RH Strain}

In order to verify the effects of COX-2 inhibitors on infection

by $T$. gondii triggered by a highly virulent strain, we performed experiments using peritoneal macrophages of C. callosus. For this purpose, we cultured these macrophages in vitro, treated with COX-2 inhibitors and infected with $T$. gondii $\mathrm{RH}$ (clone 2F1) strain.

Firstly, we performed MTT assay to verify possible cytotoxicity in peritoneal macrophages treated with meloxicam or celecoxib. The treatment with meloxicam did not induce toxicity, 
A

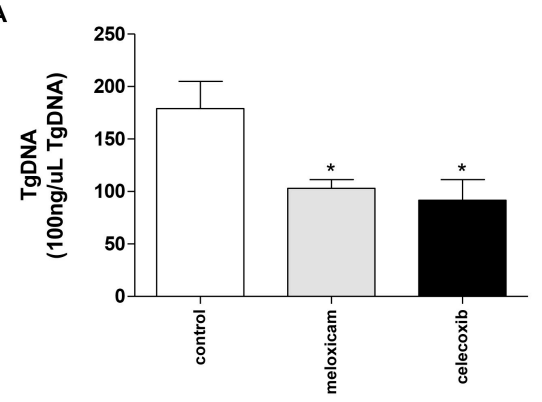

B

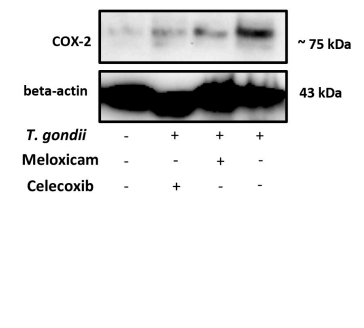

C
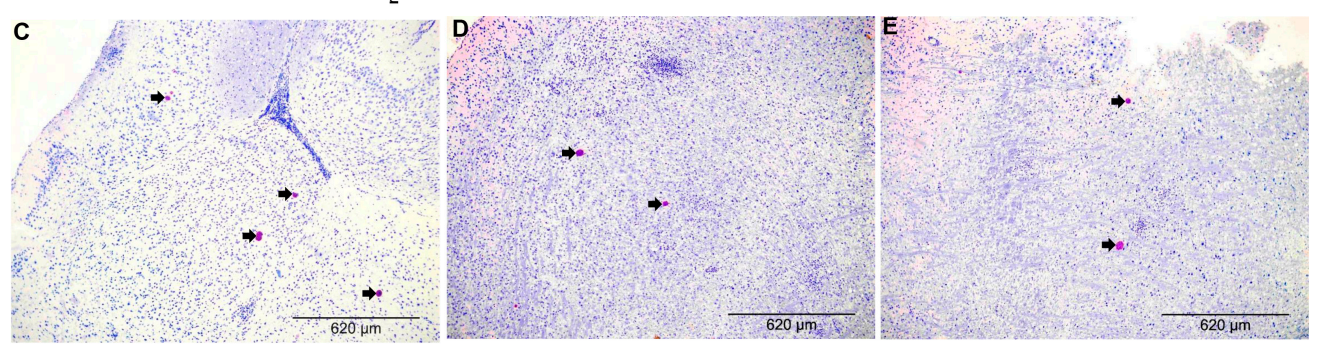

FIGURE 2 | Parasite burden and COX-2 expression in C. callosus after infection with T. gondii and treatment with COX-2 inhibitors. Females were infected orally with 50 cysts of $T$. gondii (ME49 strain), treated or untreated with meloxicam ( $0.5 \mathrm{mg} / \mathrm{kg})$ or celecoxib $(5 \mathrm{mg} / \mathrm{kg})$ daily, euthanized after 40 days of infection and treatment, and the brains collected and analyzed by real-time PCR to quantify the parasite burden (A) or Western blotting to detect COX-2 and beta-actin expressions (B). The data are shown as T. gondii DNA (TgDNA) concentration in $100 \mathrm{ng} / \mu \mathrm{L}$ total DNA (A). Differences between groups were analyzed by one-way ANOVA with the Bonferroni multiple comparison post hoc test. Significant differences in relation to untreated/infected animals (control) $\left({ }^{*} P<0.05\right)(\mathbf{A})$. Representative photomicrographs of brains of $C$. callosus infected and untreated (control) (C), infected and treated with meloxicam (D) or celecoxib (E). Immunohistochemical sections counterstained by Harris's hematoxylin. Arrows indicate parasites inside the cyst-like structures. Bar scale: $620 \mu \mathrm{m}$.

since the cell viability was preserved in all concentrations used in comparison to untreated cells (medium) (Figure 4A). However, at 250,500 , and $1000 \mu \mathrm{g} / \mathrm{mL}$, celecoxib promoted a significant reduction in cell viability in relation to untreated macrophages $(P<0.0001)$ (Figure 4A).

Next, we performed experiments to verify the $T$. gondii intracellular proliferation in peritoneal macrophages treated or untreated with COX-2 inhibitors using the non-cytotoxic concentrations established by MTT. The lower concentrations of meloxicam $(1,5$, and $10 \mu \mathrm{g} / \mathrm{mL})$ changed the number of tachyzoites slightly compared to untreated macrophages (data not shown). However, 250, 500, and $1000 \mu \mathrm{g} / \mathrm{mL}$ meloxicam and 1,5 , and $10 \mu \mathrm{g} / \mathrm{mL}$ celecoxib in peritoneal macrophages promoted a significant reduction in the number of tachyzoites in comparison to untreated cells $(P<0.0001)$ (Figure 4B). In addition, the reduction in the number of tachyzoites in macrophages treated with celecoxib or meloxicam was dosedependent, since higher doses of COX-2 inhibitors triggered the best effect on $T$. gondii control $(P=0.0008)$ (Figure 4B). In order to confirm inhibition or reduction of COX-2 expression in cells treated with meloxicam or celecoxib and infected or not by T. gondii, Western blotting was performed and it was detected inhibition of COX-2 in all treatments with meloxicam and 5 and $10 \mu \mathrm{g} / \mathrm{mL}$ celecoxib when compared to untreated and infected cells or uninfected LPS-treated cells (Figure 4C). The treatment with $1 \mu \mathrm{g} / \mathrm{mL}$ celecoxib induced only a reduction of COX2 expression in relation to infected/untreated cells, although this concentration still induced lower parasitism in peritoneal macrophage (Figures 4B,C).
Thus, it is possible to conclude that COX-2 is an important mediator during the $T$. gondii infection triggered by highly virulent strain in rodent cells.

\section{COX-2 Inhibitors Upregulated TNF and Nitrite in Peritoneal Macrophages Infected With T. gondii RH Strain}

After evaluating the parasite intracellular proliferation in peritoneal macrophages of $C$. callosus, we verified the cytokine levels in the supernatant of these cells treated or untreated with COX-2 inhibitors (Figure 5).

Macrophages infected and untreated did not alter TNF release in comparison to untreated and uninfected cells (Figure 5A). However, meloxicam and celecoxib significantly upregulated TNF levels, regardless of infection by $T$. gondii, in comparison to uninfected and untreated $(P=0.012)$ or to infected and untreated macrophages $(P=0.015)$ (Figure 5A). In relation to IL-6, infected and untreated macrophages diminished the production of this cytokine in relation to uninfected and untreated cells $(P=0.0291)$ (Figure 5B). Interestingly, both COX-2 inhibitors downmodulated IL-6 secretion regardless of infection compared to uninfected and untreated cells $(P=0.029)$ (Figure 5B), however in the presence of $T$. gondii, COX-2 inhibitors did not change the levels of IL-6 in comparison to untreated and infected cells (Figure 5B). IFN- $\gamma$, IL-17A, and IL-10 were undetected in the supernatant of peritoneal macrophages in any conditions (data not shown). 

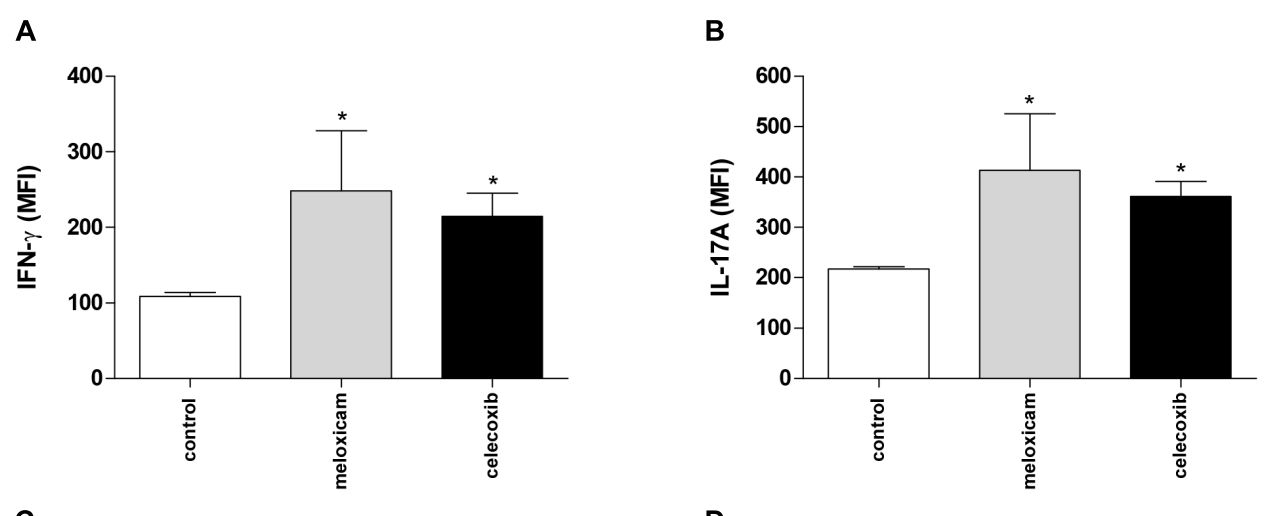

C

D
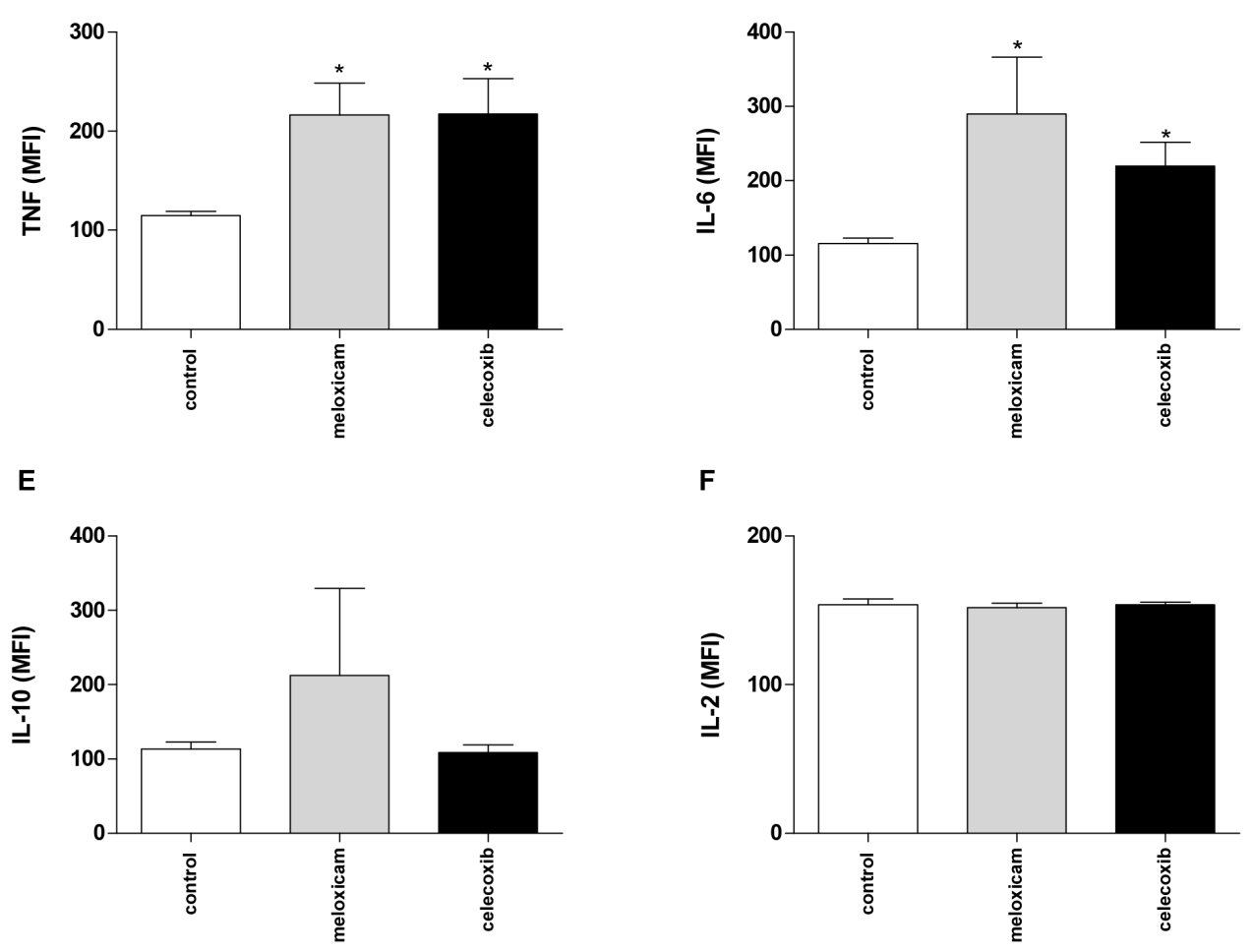

$\mathbf{F}$
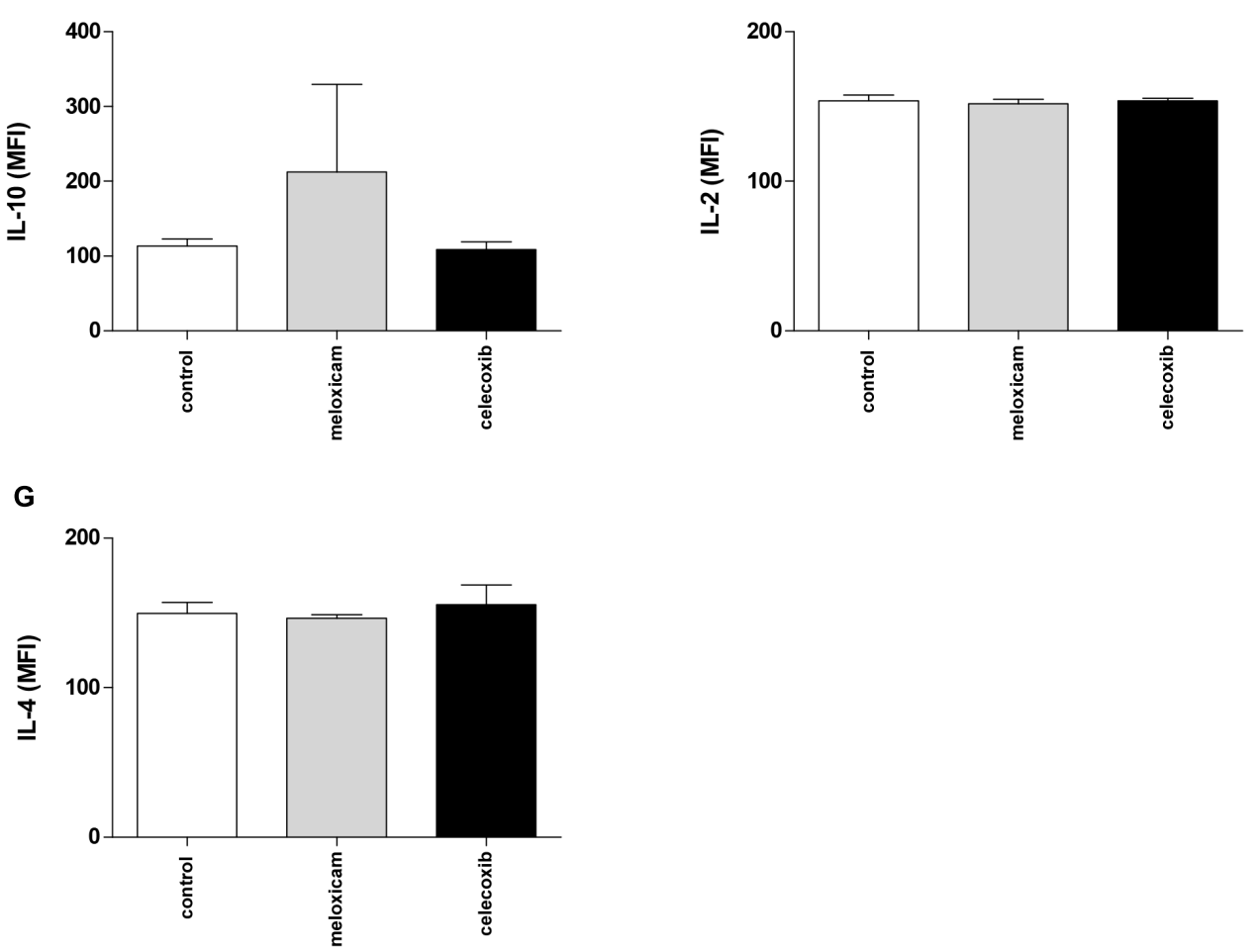

FIGURE 3 | Cytokine production in C. callosus after infection with T. gondii and treatment with COX-2 inhibitors. Females were infected orally with 50 cysts of T. gondii (ME49 strain), and treated or untreated with meloxicam $(0.5 \mathrm{mg} / \mathrm{kg})$ or celecoxib $(5 \mathrm{mg} / \mathrm{kg})$ daily for 40 days. The serum was collected for measurement of IFN- $\gamma$ (A), IL-17A (B), TNF (C), IL-6 (D), IL-10 (E), IL-2 (F), and IL-4 (G) by CBA. Data are expressed as MFI according to the standard curve. Differences between groups were analyzed by one-way ANOVA with the Bonferroni multiple comparison post hoc test. Significant differences in relation to untreated/infected animals (control) $\left(^{*} P<0.05\right)$. 

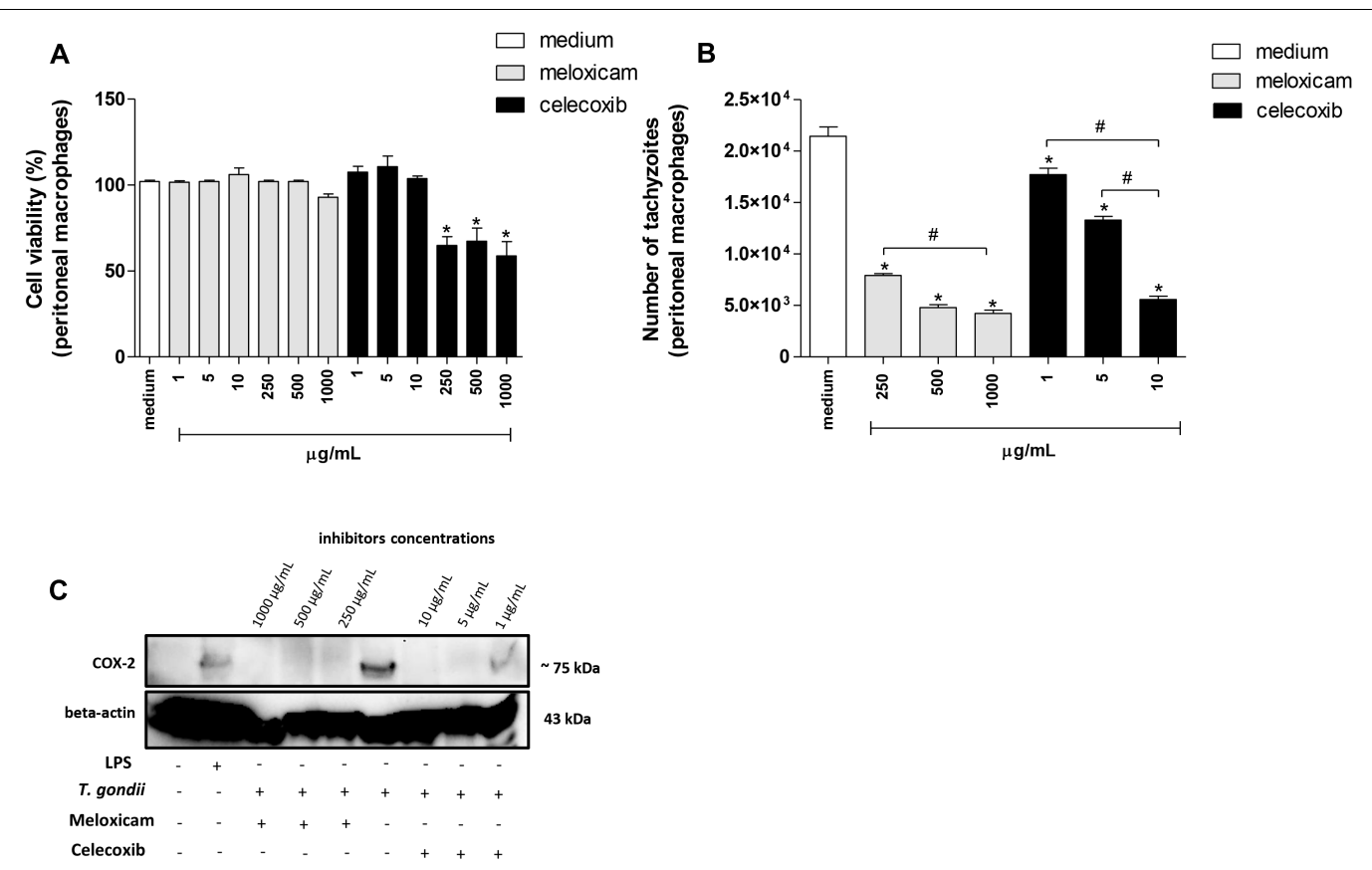

FIGURE 4 | Cell viability, number of tachyzoites and COX-2 expression in C. callosus-peritoneal macrophages treated with COX-2 inhibitors. Peritoneal macrophages were seeded in 96 -well plates $\left(1 \times 10^{5}\right.$ cells/200 $\left.\mu \mathrm{L}\right)$ in RPMl medium at $37^{\circ} \mathrm{C}$ and $5 \% \mathrm{CO}_{2}$. After $24 \mathrm{~h}$, the cells were treated or untreated with meloxicam or celecoxib in several concentrations for an additional $24 \mathrm{~h}$ and submitted to MTT assay (A). Data are expressed as percentage of viable cells (\% cell viability) in comparison to untreated cells ( $100 \%$ of cell viability). Data are shown as mean \pm SEM from two independents experiments with six replicates (A). In parallel, peritoneal macrophages were seeded in 96 -well plates $\left(1 \times 10^{5}\right.$ cells/200 $\left.\mu \mathrm{L}\right)$ for $24 \mathrm{~h}$, infected with $\mathrm{T}$. gondii tachyzoites ( $2 \mathrm{~F} 1$ clone, $\mathrm{RH}$ strain), treated or untreated with meloxicam or celecoxib for additional $24 \mathrm{~h}$ and submitted to $T$. gondii intracellular proliferation assay by $\beta$-galactosidase colorimetric reaction (B). Data are shown as mean \pm SEM of the number of tachyzoites from three independents experiments with six replicates (B). Differences between groups were analyzed by one-way ANOVA with the Bonferroni multiple comparison post hoc test. Significant differences in relation to untreated/uninfected (medium, A) or untreated/infected cells (medium, B) $\left({ }^{*} P<0.05\right)$, and different concentrations of COX-2 inhibitors $\left({ }^{\#} P<0.05\right)$. (C) Peritoneal macrophages $\left(1 \times 10^{6}\right.$ cells $/ 2000 \mu \mathrm{L}$ in six-well plates) were infected or not and treated or not with meloxicam or celecoxib in RPMl medium during $24 \mathrm{~h}$. As positive control, peritoneal macrophages were not infected and only treated with $1 \mu \mathrm{g} / \mathrm{mL}$ LPS. Then, macrophages were lysed and submitted to Western blotting for COX-2 and beta-actin detections.

When we investigated nitrite production, there was an increase in production in infected and untreated macrophages in relation to uninfected and untreated cells $(P<0.0001)$ (Figure 5C). Furthermore, all COX-2 inhibitors significantly upregulated nitrite release, regardless of infection, in comparison to uninfected and untreated or to infected and untreated macrophages $(P<0.0001)$ (Figure 5C). Also, the higher doses of meloxicam triggered increased nitrite levels when compared to all doses of celecoxib $(P<0.0001)$ (Figure 5C).

\section{COX-2 Inhibitors Reduced the T. gondii Intracellular Proliferation and $\mathrm{PGE}_{2}$ Restored the Parasite Growth in THP-1 Cells Infected With RH Strain}

After to verify the role of COX-2 during T. gondii infection in rodent cells and tissues, we also observed the function of COX-2 in human cells. For this purpose, we performed the same experiments with human monocyte cells (THP-1 cell line) using only one concentration of meloxicam $(250 \mu \mathrm{g} / \mathrm{mL})$ or celecoxib $(10 \mu \mathrm{g} / \mathrm{mL})$. Firstly, we verified the cell viability in THP-1 cells treated with meloxicam or celecoxib and no significant change was detected (data not shown), as observed for peritoneal macrophage.

Next, we investigated the T. gondii intracellular proliferation in THP-1 cells. Both COX-2 inhibitors reduced significantly the number of tachyzoites in comparison to untreated cells $(P<0.0001)$ (Figure 6A). After, we confirmed the COX-2 inhibition in THP-1 cells treated with meloxicam or celecoxib by Western blotting. As presented in Figure 6B, uninfected and untreated THP-1 cells demonstrated basal level of COX-2 expression, while infected and untreated cells showed upregulation of COX-2 in relation to respective control. Furthermore, infected THP-1 cells treated with meloxicam or celecoxib showed reduced COX-2 expression when compared to untreated/infected cells (Figure 6B).

In a second step of the experiments with human cells, we investigated if the role of COX-2 during infection with T. gondii in THP-1 cells was dependent of $\mathrm{PGE}_{2}$. Then, we treated THP-1 cells with several concentrations of $\mathrm{PGE}_{2}$ and it was detected increased number of tachyzoites in relation to infected and untreated cells (medium) $(P<0.0001)$ or infected and DMSO-treated cells $(P<0.0001)$ (Figure 6C). In addition, we verified that higher concentrations of $\mathrm{PGE}_{2}$ ( 8 to $80 \mathrm{ng} / \mathrm{mL}$ ) and doses from 20 to $80 \mathrm{ng} / \mathrm{mL}$ triggered 

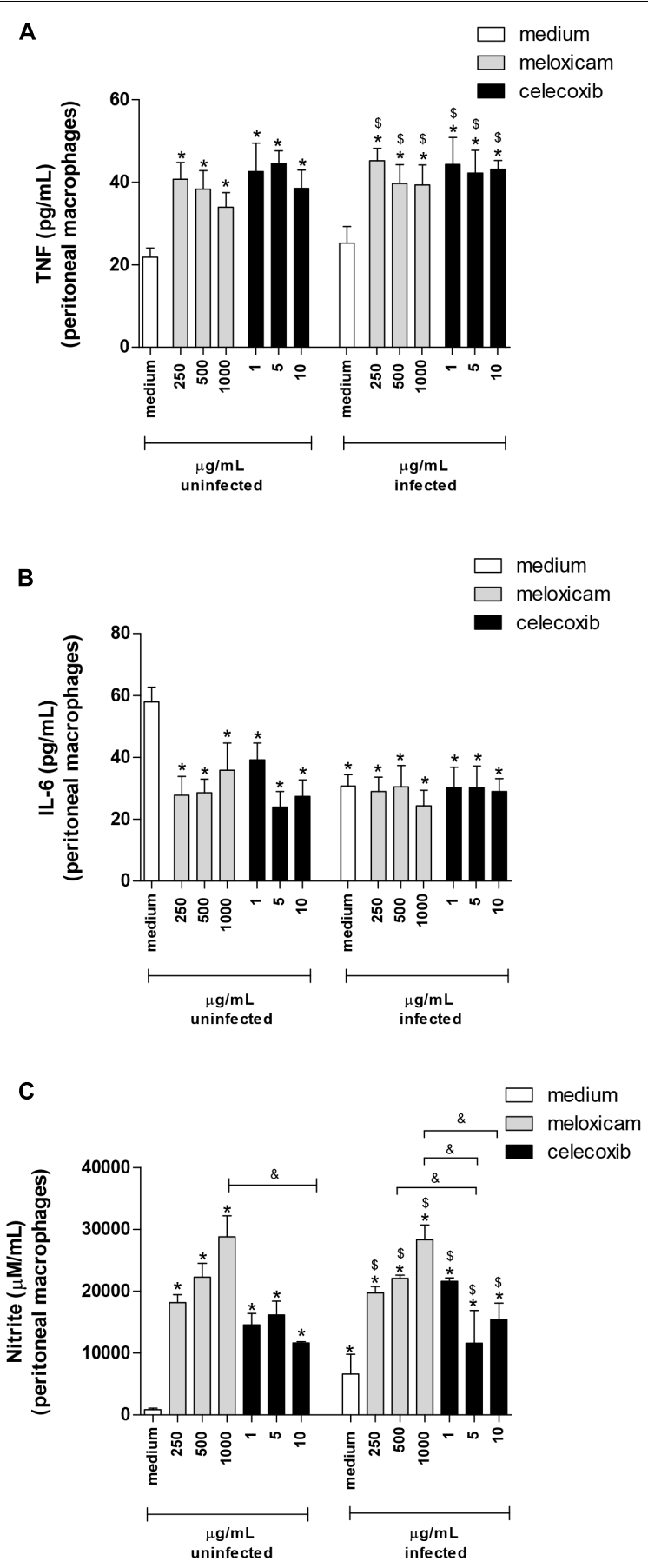

FIGURE 5 | Cytokine and nitrite production in C. callosus-peritoneal macrophages treated with COX-2 inhibitors. Peritoneal macrophages were seeded in 96 -well plates $\left(1 \times 10^{5}\right.$ cells $\left./ 200 \mu \mathrm{L}\right)$ for $24 \mathrm{~h}$, infected or not with T. gondii tachyzoites (2F1 clone, $\mathrm{RH}$ strain), treated or untreated with meloxicam or celecoxib for additional $24 \mathrm{~h}$ and the supernatants collected for measurement of TNF (A) and IL-6 (B) by sandwich ELISA, or nitrite (C) by the Griess method. Data are shown as mean \pm SEM from three independent experiments with six replicates. Differences between groups were analyzed by two-way ANOVA with the Bonferroni post hoc test. Significant differences in relation to untreated/uninfected cells (medium) $\left({ }^{*} P<0.05\right)$, untreated/infected cells (medium) $\left({ }^{\$} P<0.05\right)$, and different concentrations of COX-2 inhibitors regardless of infection $\left({ }^{\&} P<0.05\right)$. greater number of tachyzoites if compared to 0.015 and $0.150 \mathrm{ng} / \mathrm{mL}(P<0.0001)$ or $8 \mathrm{ng} / \mathrm{mL}(P<0.0001)$, respectively (Figure 6C). Finally, we blocked COX-2 expression and restored $\mathrm{PGE}_{2}$ when added exogenous levels of this lipid mediator in cells treated with meloxicam or celecoxib. As observed in Figures 6A,C, 0.150 and $80 \mathrm{ng} / \mathrm{mL} \mathrm{PGE}_{2}$ increased the number of tachyzoites $(P<0.0001)$ in dose-dependent manner $(P<0.0001)$ and meloxicam or celecoxib reduced the parasitism $(P<0.0001)$ in THP-1 cells in comparison to untreated cells or DMSO-treated cells (Figure 6D). However, when exogenous levels of $\mathrm{PGE}_{2}$ were added in THP-1 cells treated with COX-2 inhibitors, there was a reversion in the effect of meloxicam or celecoxib, since higher parasite intracellular proliferation was detected when compared to untreated cells $(P<0.0001)$, DMSO-treated cells $(P<0.0001)$ and meloxicam $(P<0.0001)$ or celecoxib-treated cells $(P<0.01)$ (Figure 6D).

Thus, it is possible to conclude that COX-2 is an important mediator during the T. gondii infection triggered by highly virulent strain in human host cells, and this effect is associated with $\mathrm{PGE}_{2}$.

\section{COX-2 Inhibitors Upregulated MIF, TNF, and Nitrite and Downmodulated IL-8 and IL-10 in THP-1 Cells Infected With T. gondii RH Strain}

After evaluating the parasite intracellular proliferation in THP1 cells, we verified the cytokine levels in the supernatant of these cells treated or untreated with COX-2 inhibitors and/or exogenous concentrations of $\mathrm{PGE}_{2}$ (Figure 7). The treatment with only DMSO $(0.022 \%)$ did not change the cytokine profile in relation to untreated cells (medium), regardless of infection with T. gondii (Figures 7A-E).

Infected and untreated THP-1 cells augmented MIF $(P<0.05)$, TNF $(P=0.0005)$ and nitrite $(P<0.0001)$ production when compared to uninfected and untreated cells (Figures 7A,C,E). However, in the presence of T. gondii, $\mathrm{PGE}_{2}$ treated cells reduced significantly the MIF $(P<0.05)$, TNF $(P<0.01)$ and nitrite $(P<0.0001)$ release, while meloxicam and celecoxib increased these productions $(P<0.0001)$ if compared to infected and untreated cells (Figures 7A,C,E). Additionally, celecoxib induced higher MIF secretion in comparison to cells treated with meloxicam $(P<0.0001)$ (Figure 7A). Interestingly, when infected THP-1 cells were treated with COX-2 inhibitor (meloxicam or celecoxib) and $\mathrm{PGE}_{2}$, regardless $\mathrm{PGE}_{2}$ dose, the MIF $(P<0.0001)$, TNF $(P<0.0001)$ and nitrite $(P<0.0001)$ productions were significantly reduced when compared to respective control (infected and meloxicam or celecoxib-treated cells) (Figures $7 \mathbf{A}, \mathbf{C}, \mathbf{E}$ ), although the treatment of infected cells with celecoxib plus $\mathrm{PGE}_{2}$ induced more MIF secretion in relation to infected cells and treated with meloxicam plus $\mathrm{PGE}_{2}(P<0.0001)$ or infected and untreated cells $(P<0.0001)$ (Figure 7A). Also, infected cells treated with meloxicam plus $\mathrm{PGE}_{2}$ reduced the $\operatorname{MIF}(P<0.05)$ and TNF $(P<0.0001)$ production in relation to untreated and infected cells (Figures 7A,C). 


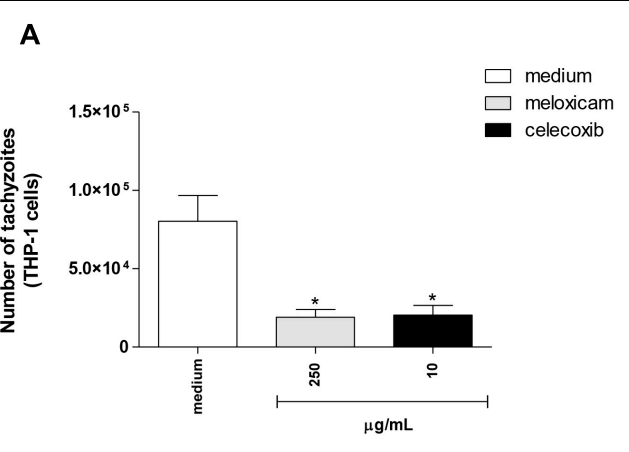

C

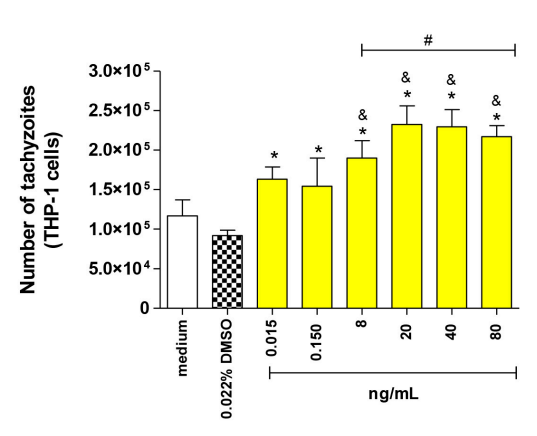

B

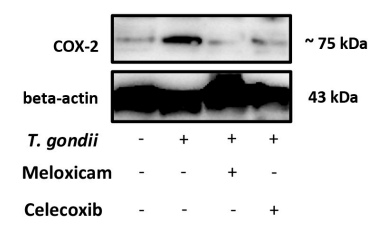

D

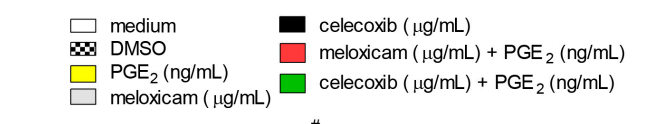

$\square$ medium $\infty$ DMSO

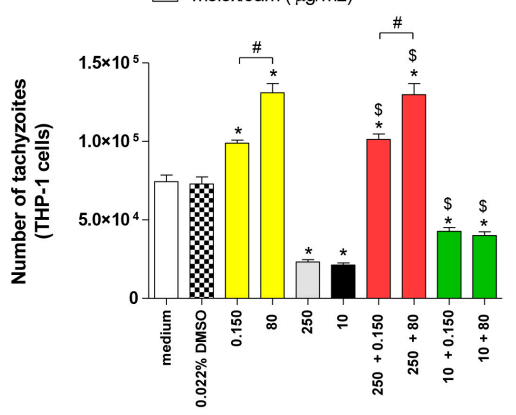

FIGURE 6 | Number of tachyzoites and COX-2 expression in THP-1 cells treated with COX-2 inhibitors and/or PGE 2 . THP-1 cells were seeded in 96-well plates $\left(3 \times 10^{4}\right.$ cells $\left./ 200 \mu \mathrm{L}\right)$ for $24 \mathrm{~h}$, infected with $\mathrm{T}$. gondii tachyzoites (2F1 clone, RH strain), treated or untreated with meloxicam or celecoxib for additional $24 \mathrm{~h}$, and submitted to T. gondii intracellular proliferation assay by $\beta$-galactosidase colorimetric reaction (A). In parallel, THP-1 cells $\left(1 \times 10^{6}\right.$ cells/2000 $\mu \mathrm{L}$ in 6 -well plates) were infected or not and treated or not with meloxicam or celecoxib in RPMI medium during $24 \mathrm{~h}$. Then, THP-1 cells were lysed and submitted to Western blotting for COX-2 and beta-actin detections (B). After, THP-1 cells $\left(3 \times 10^{4}\right.$ cells/200 $\mu \mathrm{L}$ in 96 -well plates) were infected (2F1 clone) and treated with several concentrations of $\mathrm{PGE}_{2}$ for additional $24 \mathrm{~h}$ (C), or THP-1 cells were infected and treated with meloxicam or celecoxib plus PGE 2 for $24 \mathrm{~h}$ (D), and all conditions submitted to T. gondii intracellular proliferation assay by $\beta$-galactosidase colorimetric reaction. DMSO (0.022\%) was used to exclude any effect of DMSO in the parasitism. Data are shown as mean \pm SEM of the number of tachyzoites from two independents experiments with eight replicates. Differences between groups were analyzed by one-way ANOVA with the Bonferroni multiple comparison post hoc test. Significant differences in relation to untreated/infected cells (medium) or infected/DMSO-treated cells $\left({ }^{*} P<0.05, \mathbf{A}, \mathbf{C}, \mathbf{D}\right)$, between 0.015 or $0.150 \mathrm{ng} / \mathrm{mL}$ and $8-80 \mathrm{ng} / \mathrm{mL} \mathrm{PGE}$ ( ${ }^{\&} P<0.05$, C), between different concentrations of PGE 2 or meloxicam plus PGE 2 $\left({ }^{\#} P<0.05, \mathbf{C , D}\right)$, and between COX-2 inhibitors plus $\mathrm{PGE}_{2}$ and respective control (infected and meloxicam or celecoxib-treated cells) $(\$ P<0.05$, $\mathbf{D})$.

In relation to IL-8 and IL-10, infected THP-1 cells treated with PGE 2 increased IL-8 $(P<0.0001)$ and IL-10 $(P<0.0001)$ production, while meloxicam $(P<0.05)$ and celecoxib $(P<0.05)$ reduced it when compared to untreated and infected cells (Figures 7B,D). However, the double treatment of infected cells with COX-2 inhibitors and exogenous $\mathrm{PGE}_{2}$ increased IL-8 $(P<0.0001)$ and IL-10 $(P<0.0001)$ release in comparison to respective control (infected and meloxicam or celecoxibtreated cells) (Figures 7B,D). Furthermore, infected cells treated with meloxicam plus $80 \mathrm{ng} / \mathrm{mL} \mathrm{PGE}_{2}$ produced more IL- 8 than meloxicam plus $0.150 \mathrm{ng} / \mathrm{mL} \mathrm{PGE}(P<0.001)$ or infected and untreated cells $(P<0.001)$ or celecoxib plus $80 \mathrm{ng} / \mathrm{mL}$ PGE $_{2}(P<0.001)$ (Figure 7B). IFN- $\gamma$, IL-6 and TGF- $\beta 1$ did not show significant differences in THP-1 cells under any condition (data not shown).

We also measured cytokines and nitrite in THP-1 cells treated with meloxicam, celecoxib, and $\mathrm{PGE}_{2}$ in the absence of $T$. gondii infection in order to verify the effect of all treatments without interference of the parasite. Again, the treatment with DMSO $(0.022 \%)$ did not change the cytokine profile in THP-1 cells (Supplementary Figures 1A-E). As observed for infected THP-1 cells, meloxicam and celecoxib triggered higher levels of MIF $(P<0.0001)$, TNF $(P<0.0001)$ and nitrite $(P<0.0001)$ when compared to untreated cells (Supplementary Figures 1A,C,E), while the treatment with $\mathrm{PGE}_{2}$ in uninfected cells induced only reduction of TNF in relation to untreated cells $(P<0.05)$ (Supplementary Figure 1C) and did not alter the levels of MIF or nitrite (Supplementary Figures 1A,E). When THP-1 cells were blocked to COX2 expression with meloxicam or celecoxib and treated with $\mathrm{PGE}_{2}$, the levels of $\operatorname{MIF}(P<0.0001)$, TNF $(P<0.0001)$ and nitrite $(P<0.05)$ were downmodulated in comparison to respective control (uninfected and meloxicam or celecoxibtreated cells) (Supplementary Figures 1A,C,E) or to untreated condition for TNF in cells treated with meloxicam plus $\mathrm{PGE}_{2}$ $(P<0.05)$ (Supplementary Figure 1C), except for nitrite in cells treated with meloxicam plus $0.150 \mathrm{ng} / \mathrm{mL} \mathrm{PGE}_{2}$ (Supplementary Figure 1E). The nitrite levels were upregulated in THP-1 cells treated with meloxicam plus $80 \mathrm{ng} / \mathrm{mL} \mathrm{PGE}_{2}$ and celecoxib plus $\mathrm{PGE}_{2}$ in relation to untreated cells $(P<0.0001)$, but 
A
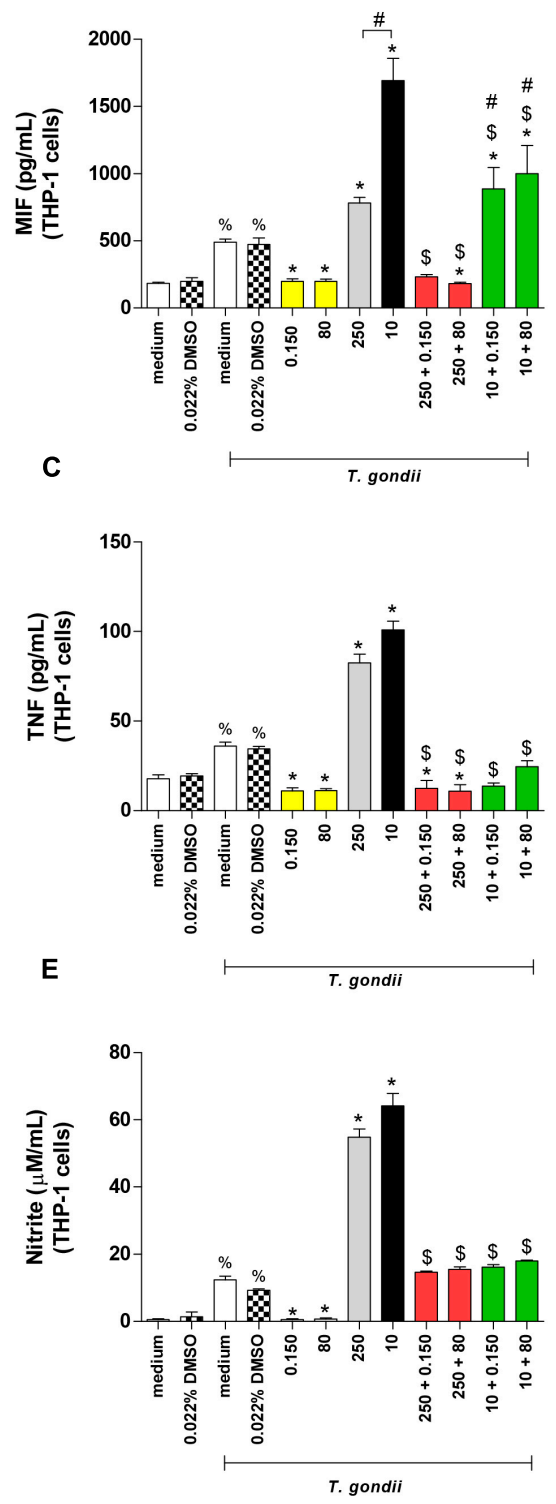

B
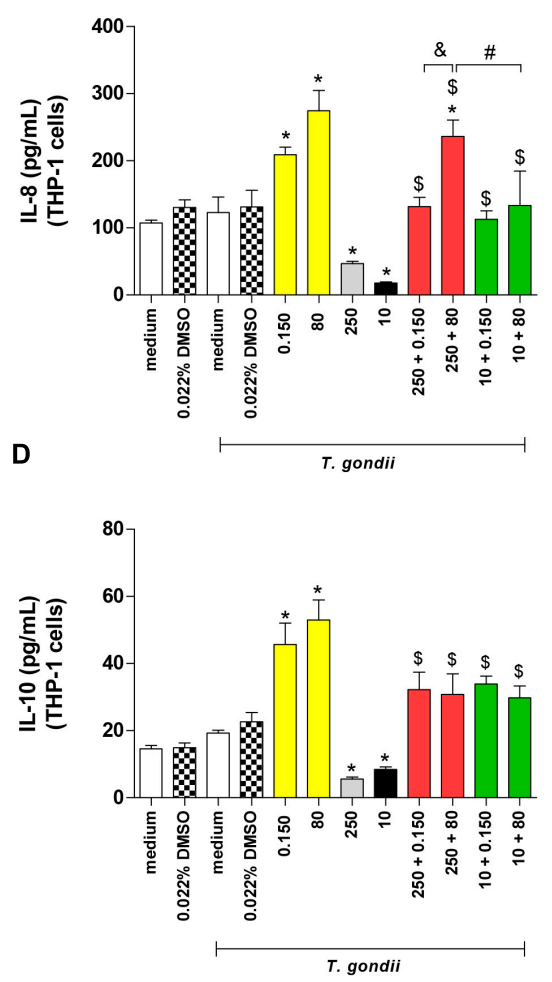

FIGURE 7 | Cytokine and nitrite production in infected THP-1 cells treated with COX-2 inhibitors and/or PGE 2 . THP-1 cells were seeded in $96-$ well plates $\left(3 \times 10^{4}\right.$ cells/200 $\mu \mathrm{L}$ ) for $24 \mathrm{~h}$, infected with T. gondii tachyzoites (2F1 clone, RH strain), and treated or untreated with meloxicam or celecoxib in the presence or absence of $\mathrm{PGE}_{2}$ for additional $24 \mathrm{~h}$. The supernatants were collected for measurement of MIF (A), IL-8 (B), TNF (C), and IL-10 (D) by sandwich ELISA, or nitrite (E) by the Griess method. DMSO (0.022\%) was used to exclude any effect of DMSO in the cytokine or nitrite production. Data are shown as mean \pm SEM from two independents experiments with eight replicates. Differences between groups were analyzed by two-way ANOVA with the Bonferroni post hoc test. Significant differences in relation to untreated/uninfected cells (medium) or uninfected/DMSO-treated cells $(\% P<0.05)$, between untreated/infected cells (medium) or infected/DMSO-treated cells ( ${ }^{*} P<0.05$ ), between different concentrations of COX-2 inhibitors in the absence or presence of PGE 2 ( $P<0.05$ ), between different concentrations of meloxicam plus PGE $2\left({ }^{\&} P<0.05\right)$, and between COX-2 inhibitors plus $\mathrm{PGE}_{2}$ and respective control (infected and meloxicam or celecoxib-treated cells) $(\$ P<0.05)$.

the levels were still lower if compared to respective control $(P<0.05)$ (Supplementary Figure 1E).

Regarding to IL-8 and IL-10 in uninfected THP-1 cells, all doses of $\mathrm{PGE}_{2}$ triggered upregulation of these cytokines when compared to untreated cells $(P<0.0001)$ (Supplementary Figures 1B,D). Only celecoxib was able to downmodulate IL-10 in relation to untreated cells $(P<0.05)$
(Supplementary Figure 1D), however the double treatment with any COX-2 inhibitor plus $\mathrm{PGE}_{2}$ induced increased IL-8 and IL-10 production in comparison to respective control (uninfected and meloxicam or celecoxib-treated cells) $(P<0.01)$ or untreated cells $(P<0.01)$ (Supplementary Figures 1B,D), except for IL-8 in THP-1 treated with celecoxib plus $0.150 \mathrm{ng} / \mathrm{mL}$ $\mathrm{PGE}_{2}$ in relation to untreated cells (Supplementary Figure 1B). 


\section{Actions Triggered by COX-2 Inhibitors During Infection by T. gondii With Moderately (ME49) and Highly Virulent (RH) Strains}

A proposed scheme of the actions induced by COX-2 inhibitors in in vivo and in vitro experimental models is shown in Figure 8. When C. callosus females were infected with T. gondii (ME49 strain) and treated with COX-2 inhibitors for 40 days, the brains of these animals presented reduced parasite burden, while the serum showed upregulation of pro-inflammatory cytokines (IFN- $\gamma$, TNF, IL-17A, and IL-6) (Figure 8A). In addition, when peritoneal macrophages from $C$. callosus females were treated with COX-2 inhibitors and infected with T. gondii (2F1 clone, RH strain) for $24 \mathrm{~h}$, the cells demonstrated a lower number of tachyzoites, indicating a reduced parasite intracellular proliferation, and supernatants showed an upregulation of pro-inflammatory mediators (TNF and nitrite) (Figure 8B). When THP-1 cells were infected (2F1 clone) and treated with COX-2 inhibitors during $24 \mathrm{~h}$ (middle panel), there was a reduced number of tachyzoites and an upregulation of proinflammatory cytokines (MIF, TNF) and nitrite in comparison to untreated/infected cells (left panel) (Figure 8C). Finally, THP1 cells treated with COX-2 inhibitors plus exogenous levels of $\mathrm{PGE}_{2}$ (right panel) demonstrated upregulation of IL-10 and IL-8, and downmodulation of pro-inflammatory mediators (MIF, TNF, and nitrite) in relation to untreated/infected (left panel) or only meloxicam, celecoxib-treated cells (middle panel) (Figure 8C). Thus, it is plausible to conclude that COX-2 is an important mediator that favor $T$. gondii replication, since its blockage triggers significant control of parasitism in rodent and human cells by upregulating important pro-inflammatory mediators involved in the immune response against this parasite. The exogenous $\mathrm{PGE}_{2}$ restored the $\mathrm{PGE}_{2}$ in THP-1 cells blocked to COX-2 and, consequently, induced higher parasitism by reducing pro-inflammatory mediators and increasing anti-inflammatory mediators (IL-10).

\section{DISCUSSION}

Prostaglandins are lipid mediators able to regulate many functions during an inflammation, such as cytokine production and cellular activation/maturation (Nagamatsu and Schust, 2010; Kalinski, 2012). The production of $\mathrm{PGE}_{2}$ occurs when arachidonic acid is converted into prostaglandins by enzymes called cyclooxygenases, as previously described (Batlouni, 2010; Agard et al., 2013; Sharma et al., 2017; Martínez-Colón and Moore, 2018). Many studies demonstrate the role of COX-2 and $\mathrm{PGE}_{2}$ during infections triggered by pathogens (Michelin et al., 2005; Abdalla et al., 2008; Tatakihara et al., 2008; Moraes et al., 2015), however there are no studies demonstrating association between COX-2 and susceptibility to T. gondii infection. Thus, the aim of the present study was to investigate the role of COX-2 during infection by $T$. gondii in in vivo and in vitro experimental models. The findings obtained can stimulate study into new therapeutic targets to prevent or treat the acquired toxoplasmosis, a severe public health problem in many countries (Dubey et al., 2012).

Firstly, we verified body-weight change and morbidity scores in females infected with $T$. gondii and treated or untreated with COX-2 inhibitors. In general, infected and COX-2 inhibitortreated females presented higher body-weight change and lower morbidity score in comparison to infected and untreated females. Some studies demonstrated that the use of non-steroidal antiinflammatories has been associated with upper gastrointestinal complications (Massó et al., 2010; Castellsague et al., 2012) and cardiovascular and cerebrovascular risk (Fanelli et al., 2017). Thus, it is possible that the meloxicam and celecoxib used to treat the animals triggered blocking of COX-2 and, at the same time, gastrointestinal disorders, promoting body weight loss. On the other hand, the differences between morbidity score in treated and untreated females can be associated to the parasite burden, since inhibitor-treated animals showed reduced tissue parasitism and lower morbidity compared to untreated animals. Then, we can conclude that high parasite burden is proportional to high morbidity score, leading to the symptoms observed in the untreated females.

Next, we observed that meloxicam and celecoxib significantly reduced brain parasitism during the chronic phase of infection triggered by ME49-moderately virulent strain. Additionally, we performed experiments with $\mathrm{RH}$-highly virulent strain in order to verify whether the same phenomena could be repeated. For this purpose, we used as in vitro experimental model peritoneal macrophages of $C$. callosus females and human monocyte cells (THP-1 cell line) in order to determine if the role of COX-2 during infection by $T$. gondii would be the same in two different cell types. We verified that peritoneal macrophages and THP1 cells infected with T. gondii (RH strain - 2F1 clone) and treated with meloxicam or celecoxib also reduced significantly the parasite burden, since a lower number of tachyzoites was observed in these cells. Therefore, all COX-2 inhibitors are able to dampen the T. gondii proliferation in vivo and in vitro conditions, regardless of strain or cell types.

Many studies are in agreement with our findings, especially using T. cruzi as pathogen. As previously described, mice infected with T. cruzi showed reduced parasitism in blood and cardiac muscle when treated with COX-2 inhibitors (meloxicam, etoricoxib, sodium salicylate, aspirin, or celecoxib) (Michelin et al., 2005; Abdalla et al., 2008; Tatakihara et al., 2008). However, Guerrero et al. (2015) did not verify significant changes in the number of $T$. cruzi parasites in cardiac muscle, although the authors have demonstrated that knockout mice for COX-2 showed $30 \%$ reduction in blood parasite numbers. Also, COX inhibitors diminished the internalization of T. cruzi in mouse peritoneal macrophages (Malvezi et al., 2014) and human monocytes (Carvalho de Freitas et al., 2017), and COX-2 and $\mathrm{PGE}_{2}$ are mentioned as inductors of the immunosuppression observed during the acute phase of Chagas disease, favoring the persistence of the parasite in host cells (Pinge-Filho et al., 1999). Additionally, a study has demonstrated that curcumin, a natural product isolated from Curcuma longa L. (Zingiberaceae), enhanced survival and provoked a relevant inflammatory response in the heart of mice infected with 
A

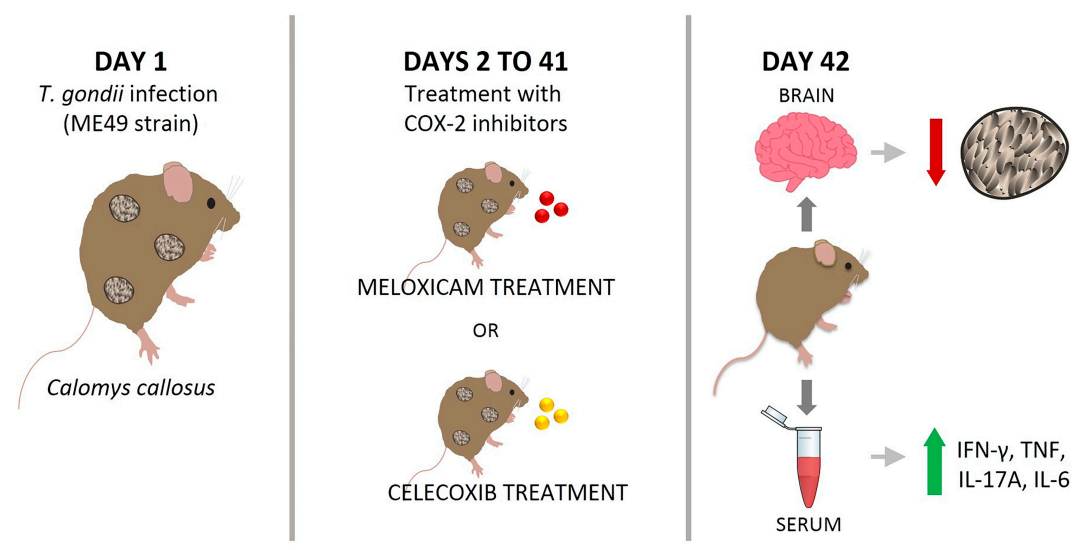

B

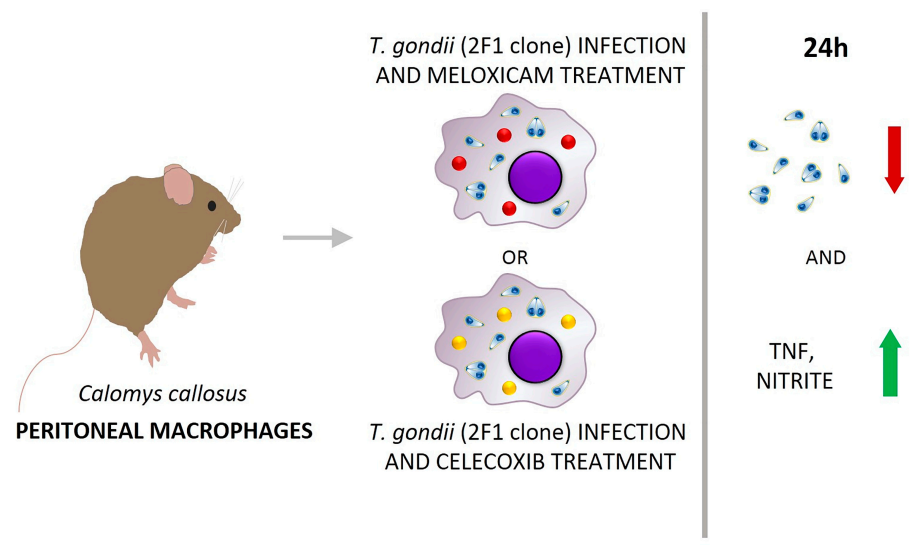

C

T. gondii (2F1 clone) INFECTION

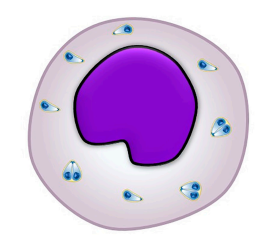

HUMAN THP-1 CELLS
T. gondii (2F1 clone) INFECTION AND MELOXICAM TREATMENT

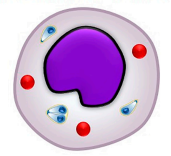

OR

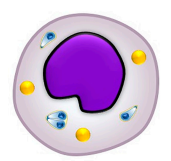

T. gondii (2F1 clone) INFECTION AND CELECOXIB TREATMENT

MIF, TNF, NITRITE
T. gondii (2F1 clone) INFECTION, MELOXICAM AND PGE ${ }_{2}$ TREATMENTS

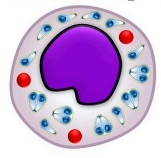

OR

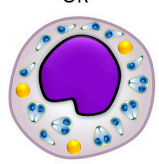

T. gondii (2F1 clone) INFECTION, CELECOXIB AND PGE ${ }_{2}$ TREATMENTS

IL-10, IL-8

MIF, TNF, NITRITE

$\begin{array}{lll}\text { T. gondii CYSTS (ME49 STRAIN) } & \ddots \text { MELOXICAM } & \text { U UPREGULATION } \\ \text { T. gondii TACHYZOITES (2F1 CLONE) } & \ddots \text { CELECOXIB } & \nabla \text { REDUCTION }\end{array}$

FIGURE 8| Proposed model of actions induced by COX-2 inhibitors in in vivo and in vitro experimental models. (A) C. callosus infected with T. gondii (ME49 strain) and treated with COX-2 inhibitors presented reduced parasite burden in brain and upregulation of pro-inflammatory cytokines (IFN- $\gamma$, TNF, IL-17A, and IL-6). (B) C. callosus-peritoneal macrophages treated with COX-2 inhibitors and infected with $T$. gondii (RH strain) demonstrated a reduced parasite intracellular proliferation and upregulation of pro-inflammatory mediators (TNF and nitrite). (C) THP-1 cells treated with COX-2 inhibitors and infected with T. gondii (RH strain) (middle panel) presented reduced parasite proliferation and upregulation of pro-inflammatory mediators (MIF, TNF, and nitrite) in comparison to untreated/infected cells (left panel); while THP-1 cells treated with COX-2 inhibitors plus exogenous levels of PGE $_{2}$ (right panel) demonstrated increased parasitism, upregulation of IL-10 and IL-8, and downmodulation of pro-inflammatory mediators (MIF, TNF, and nitrite). 
T. cruzi, since curcumin was able to block COX-2 induction and $\mathrm{PGE}_{2}$ release (Hernández et al., 2016). A recently published study showed that celecoxib significantly inhibited T. cruzi infection in dendritic cell-enriched peripheral human blood mononuclear cell populations, but aspirin, a non-selective COX-1 and COX-2 inhibitor, did not present the same effect (Lonien et al., 2017). The effect of celecoxib in reducing the T. cruzi invasion in human dendritic cells was dose-dependent (Lonien et al., 2017), according to our findings in C. calomys peritoneal macrophages. Previous studies also demonstrated association between $\mathrm{PGE}_{2} / \mathrm{COX}-2$ axis and susceptibility to Leishmania protozoa. A murine mononuclear phagocyte derived from B-1 cells treated with COX-2 inhibitors and infected with L. major presented lower numbers of intracellular amastigotes and reduced $\mathrm{PGE}_{2}$ and IL-10 release (Arcanjo et al., 2015), and macrophages infected with $L$. donovani induced COX-2 expression in a toll like receptor-2 (TLR2)-dependent-manner, favoring the infection in these cell types (Bhattacharjee et al., 2016). Thus, it is clear that COX-2 and $\mathrm{PGE}_{2}$ can favor the persistence of T. cruzi and Leishmania in the host.

However, just a small number of studies have verified that COX-2 is induced by T. gondii infection, and none of these studies demonstrated that COX-2 is directly involved with Toxoplasma susceptibility. As previously described, T. gondii was associated to high levels of $\mathrm{PGE}_{2}$ and increased COX-2 expression in mouse peritoneal macrophage or skeletal muscle cells (Gomes et al., 2014; Mota et al., 2014). In addition, human epithelial uterine cells infected with T. gondii also showed enhanced COX-2 and $\mathrm{PGE}_{2}$ expression, although no association was observed in relation to parasite burden (Kim et al., 2006). Thus, our present study is the first to show the role of COX-2 during T. gondii infection with moderately or highly virulent strains.

Considering that $\mathrm{PGE}_{2}$ is a lipid mediator derived from arachidonic acid by action of COX-2 (Martínez-Colón and Moore, 2018), and that COX-2 inhibitors (meloxicam and celecoxib) reduced $T$. gondii proliferation in peritoneal macrophages and THP-1 cells, we investigated the effect of $\mathrm{PGE}_{2}$ restoration in THP-1 cells treated with meloxicam or celecoxib, in order to prove that the role of COX-2 during T. gondii infection is dependent of this lipid mediator. As result, it was observed the reestablishment of $T$. gondii growth in THP-1 cells blocked for COX-2 and treated with $\mathrm{PGE}_{2}$. Therefore, the role of COX-2 during T. gondii infection is $\mathrm{PGE}_{2}$ dependent. Our findings are in agreement with Lonien et al. (2017). Human dendritic cells infected by T. cruzi and treated with celecoxib plus $\mathrm{PGE}_{2}$ presented increased internalization of trypomastigotes in comparison to cells treated with only celecoxib, indicating that $\mathrm{PGE}_{2}$ inhibition using celecoxib was reverted and restored the invasion of the parasite in the host cells (Lonien et al., 2017). Also, our previous study showed that human trophoblast cells treated with $\mathrm{PGE}_{2}$ presented higher susceptibility to T. gondii infection (RH strain), evidencing that $\mathrm{PGE}_{2}$ can facilitate parasite proliferation (Barbosa et al., 2014). Additionally, it was demonstrated that annexin A1 decreased parasitism rate in human placenta infected by $T$. gondii and it was associated with reduced levels of $\mathrm{PGE}_{2}$ and COX-2
(Oliveira-Cardoso et al., 2018). Thus, to control the parasite replication, the host cells should reduce COX-2 expression to dampen the $T$. gondii susceptibility. In this sense, it was demonstrated that mice microglia cells (BV-2 cells) infected with RH or ME49 strains downmodulated significantly COX-2 expression to control the infection (Hwang et al., 2018). Furthermore, recent studies demonstrated that C57BL/6 mice treated with T. cruzi strain Y extracellular vesicle (EV Y) induced increased cardiac parasitism and elevated parasite internalization in bone marrow-derived macrophages, and these effects were associated to lipid body formation and $\mathrm{PGE}_{2}$ production, evidencing the role of lipid bodies and $\mathrm{PGE}_{2}$ in favor the parasite growth (Lovo-Martins et al., 2018). In addition, the treatment with drugs as NS-398 and aspirin inhibited $\mathrm{PGE}_{2}$ release and reduced significantly $T$. cruzi replication in macrophages, demonstrating eicosanoids as a parasite escape mechanism (Almeida et al., 2018). Then, our study is the first to show the potential effect of COX-2 in favoring the replication of T. gondii in the host cells, regardless of strain or cell types (rodent and human cells), becoming C. callosus an excellent model to study the role of COX-2 during infections by pathogens, as T. gondii.

After verifying that COX-2 inhibitors decreased the susceptibility to T. gondii, we investigated the immune mechanisms that triggered these findings. Infected C. callosus treated with meloxicam or celecoxib upregulated IFN- $\gamma$, IL-17A, TNF and IL-6, while peritoneal macrophages or THP-1 cells treated with both COX-2 inhibitors upregulated TNF and nitrite, or TNF, MIF and nitrite, respectively. In the absence of infection, peritoneal macrophages and THP-1 cells demonstrated similar findings, since basal levels of COX-2 are observed in these cells and the inhibition of this basal expression seems to be sufficient to trigger a pro-inflammatory response. Thus, it is possible conclude that meloxicam and celecoxib induce a pro-inflammatory immune response, which triggers significant reduction in $T$. gondii infection. Many studies demonstrated the important protective role of IFN- $\gamma$, nitrite (Gazzinelli et al., 1994; Lang et al., 2007; Kemp et al., 2013; Koblansky et al., 2013; Behnke et al., 2017; Abreu-Cabral et al., 2018), IL-17A (Kelly et al., 2005), MIF (Ferro et al., 2008; Flores et al., 2008; Terrazas et al., 2010; Gomes et al., 2011, 2018; Barbosa et al., 2014), TNF and IL-6 (Castro et al., 2013; Barbosa et al., 2014, 2015) during infection by $T$. gondii. Our recent studies showed that IL-6, TNF and MIF are the most important cytokines involved in the immune response to T. gondii in human trophoblast cells, human explants from third trimester and murine maternalfetal interface, allowing a significant reduction in the vertical transmission of the parasite (Barbosa et al., 2015; Silva et al., 2017; Gomes et al., 2018). Oliveira et al. (2010) observed higher IFN- $\gamma$ and IL-2 concentrations in serum of rats infected with T. cruzi and treated with meloxicam. Also, increased nitrite production and high numbers of inflammatory infiltrates was observed in the colon of mice infected with T. cruzi and treated with COX-2 inhibitor, regardless of time of infection, or acute or chronic phase (Oda et al., 2017). Additionally, upregulation of IL-1 $\beta$, nitrite, IL-12, and IL-10 was verified in murine peritoneal macrophages (Malvezi et al., 2014) and human monocytes (Carvalho de Freitas et al., 2017) infected with T. cruzi and 
treated with aspirin-COX inhibitor. However, Lonien et al. (2017) did not verify TNF, IL-6, IL-8, IL-10, and NO production after celecoxib treatment in human dendritic cells, although the COX-2 inhibitor did control the T. cruzi infection in these cells. Therefore, the inflammatory immune response induced by both COX-2 inhibitors can be one of the mechanisms responsible for T. gondii control in vivo and in vitro conditions. Probably, other mechanisms are triggered by COX inhibitors, however future studies are necessary to verify this hypothesis. Furthermore, future experiments are necessary to verify the role of COX-2 during $T$. gondii infection in the maternal-fetal interface in order to verify whether the same findings are observed during congenital toxoplasmosis.

In THP-1 cells, we observed higher levels of MIF and lower levels of IL-8 and IL-10 during meloxicam or celecoxib treatments. IL-10 is an anti-inflammatory cytokine and it is associated with increased Toxoplasma replication in many cell types, including human trophoblast and monocyte cells (Barbosa et al., 2008, 2015; Franco et al., 2011; Castro et al., 2013). Therefore, it is possible that the lower IL-10 release in cells blocked to COX-2 helped the parasite control.

IL-8 is a member of the CXC chemokine family produced by macrophages and other cell types, and it is significantly associated to neutrophil chemoattractant and activator, then it is an important mediator during innate immune response to several pathogens and other inflammation types (Dong and Zheng, 2015). For example, IL-8 is predominant in pregnant women with positive IgM T. gondii serology (Nejad et al., 2011), and participates of immune response to Trichomonas vaginalis (Nam et al., 2012) and visceral leishmaniasis (Frade et al., 2011). Many types of extracellular signals activate intracellular pathways resulting in IL-8 release, and this cytokine has ability to trigger mitogen-activated protein kinase (MAPKs), as extracellular regulating kinase (ERK)1/2, and finally promote inflammation and granulocyte recruitment (Dong and Zheng, 2015). Sommerville et al. (2013) verified that T. gondii produces a homolog of MIF, called TgMIF, and this MIF of the parasite was able to induce IL-8 in human peripheral blood mononuclear cells (PBMC) and triggered ERK1/2 in murine bone marrow-derived macrophages. Probably, IL- 8 induced by TgMIF can attract neutrophil and immature dendritic cells to the site of infection, promoting a dissemination of the infection by host organism, thus TgMIF may play an important immunomodulatory function to favor the parasite propagation, even recruiting inflammatory cells (Sommerville et al., 2013). Our previous study demonstrated that MIF is able to control T. gondii replication only in high doses, since there is absence of ERK1/2 and $\mathrm{PGE}_{2}$ production (Barbosa et al., 2014). In the present study, we verified that higher

\section{REFERENCES}

Abdalla, G. K., Faria, G. E., Silva, K. T., Castro, E. C., Reis, M. A., and Michelin, M. A. (2008). Trypanosoma cruzi: the role of PGE2 in immune response during the acute phase of experimental infection. Exp. Parasitol. 118, 514-521. doi: 10.1016/j.exppara.2007.11.003

Abreu-Cabral, G. R., Wang, Z. T., Sibley, L. D., and DaMatta, R. A. (2018). Inhibition of nitric oxide production in activated macrophages caused by
MIF release in THP-1 cells treated with meloxicam or celecoxib contributed to control of the parasitism and, at the same time, reduced IL-8. We can speculate that both decreased IL-8 secretion plus high levels of MIF could trigger lower levels of ERK1/2 phosphorylation in THP-1 cells, and thinking about in vivo conditions, all these phenomena may dampen propagation of T. gondii for the host organism. Then, it is possible to hypothesize that IL-8 has an important role in favor the dissemination of infection, even recruiting inflammatory cells to site of infection. It can be reinforced when THP-1 cells were infected and treated with $\mathrm{PGE}_{2}$ : increased IL- 8 production and, at the same time, elevated T. gondii proliferation. However, future studies are necessary to verify the intracellular pathway triggered by IL-8 in monocytes infected by Toxoplasma.

Taken together, we can conclude that COX-2 is an immune mediator involved in the susceptibility to T. gondii regardless of strain or cell types, since the inhibition of cyclooxygenases was able to reduce infection in the host cells by triggering a classical and potent pro-inflammatory immune response. Thus, COX-2 can be a potential target for future therapeutic strategies against T. gondii infection.

\section{AUTHOR CONTRIBUTIONS}

BFB designed the experiments. AP, RS, PF, GS, IM, MR, AOG, $A R, P G, E R$, and BFB performed the experiments. AP, RS, PF, NS, and $\mathrm{BFB}$ analyzed the data. BFB, TM, JM, NS, and EF provided the reagents. BFB, PF, TM, JM, NS, and EF discussed the findings. $\mathrm{BFB}, \mathrm{MR}, \mathrm{JM}$, and EF reviewed the manuscript. All authors approved the final version of the manuscript.

\section{FUNDING}

This work was supported by Brazilian Researcher Agencies: Conselho Nacional de Desenvolvimento Científico e Tecnológico (CNPq), and Fundação de Amparo à Pesquisa do Estado de Minas Gerais (FAPEMIG). This study was financed in part by the Coordenação de Aperfeiçoamento de Pessoal de Nível Superior Brazil (CAPES) - Finance Code 001.

\section{SUPPLEMENTARY MATERIAL}

The Supplementary Material for this article can be found online at: https://www.frontiersin.org/articles/10.3389/fmicb. 2019.00225/full\#supplementary-material

Toxoplasma gondii infection occurs by distinct mechanisms in different mouse macrophage cell lines. Front. Microbiol. 9:1936. doi: 10.3389/fmicb.2018. 01936

Agard, M., Asakrah, S., and Morici, L. A. (2013). PGE(2) suppression of innate immunity during mucosal bacterial infection. Front. Cell. Infect. Microbiol. 3:45. doi: 10.3389/fcimb.2013.00045

Almeida, P. E., Toledo, D. A. M., Rodrigues, G. S. C., and D’Avila, H. (2018). Lipid bodies as sites of prostaglandin E2 synthesis during chagas disease: impact in the 
parasite escape mechanism. Front. Microbiol. 9:499. doi: 10.3389/fmicb.2018. 00499

Arcanjo, A. F., LaRocque-de-Freitas, I. F., Rocha, J. D., Zamith, D., Costa-da-Silva, A. C., Nunes, M. P., et al. (2015). The PGE2/IL-10 axis determines susceptibility of B-1 cell-derived phagocytes (B-1CDP) to Leishmania major infection. PLoS One 10:e0124888. doi: 10.1371/journal.pone.0124888

Barbosa, B. F., Gomes, A. O., Ferro, E. A. V., Napolitano, D. R., Mineo, J. R., and Silva, N. M. (2012). Enrofloxacin is able to control Toxoplasma gondii infection in both in vitro and in vivo experimental models. Vet. Parasitol. 187, 44-52. doi: 10.1016/j.vetpar.2011.12.039

Barbosa, B. F., Lopes-Maria, J. B., Gomes, A. O., Angeloni, M. B., Castro, A. S., Franco, P. S., et al. (2015). IL10, TGF betal, and IFN gamma modulate intracellular signaling pathways and cytokine production to control Toxoplasma gondii infection in BeWo trophoblast cells. Biol. Reprod. 92:82. doi: 10.1095/biolreprod.114.124115

Barbosa, B. F., Paulesu, L., Ietta, F., Bechi, N., Romagnoli, R., Gomes, A. O., et al. (2014). Suceptibility to Toxoplasma gondii proliferation in BeWo human trophoblast cells is dose-dependent of macrophage migration inhibitory factor (MIF), via ERK1/2 phosphorylation and prostaglandin E2 production. Placenta 35, 152-162. doi: 10.1016/j.placenta.2013.12.013

Barbosa, B. F., Silva, D. A. O., Costa, I. N., Mineo, J. R., and Ferro, E. A. V. (2008). BeWo trophoblast cell susceptibility to Toxoplasma gondii is increased by interferon-gamma, interleukin-10 and transforming growth factor-beta1. Clin. Exp. Immunol. 151, 536-545. doi: 10.1111/j.1365-2249.2007. 03583.x

Barbosa, B. F., Silva, D. A. O., Costa, I. N., Pena, J. D. O., Mineo, J. R., and Ferro, E. A. V. F. (2007). Susceptibility to vertical transmission of Toxoplasma gondii is temporally dependent on the preconceptional infection in Calomys callosus. Placenta 28, 624-630. doi: 10.1016/j.placenta.2006.10.011

Bartley, P. M., Wright, S., Sales, J., Chianini, F., Buxton, D., and Innes, E. A. (2006). Long-term passage of tachyzoites in tissue culture can attenuate virulence of Neospora caninum in vivo. Parasitology 133, 421-432. doi: 10.1017/ S0031182006000539

Batlouni, M. (2010). Anti-inflamatórios não esteroides: efeitos cardiovasculares, cérebro-vasculares e renais. Arq. Bras. Cardiol. 94, 556-563. doi: 10.1590/ S0066-782X2010000400019

Behnke, K., Sorg, U. R., Gabbert, H. E., and Pfeffer, K. (2017). The lymphotoxin $\beta$ receptor is essential for upregulation of IFN-induced guanylate-binding proteins and survival after Toxoplasma gondii infection. Mediators Inflamm. 2017:7375818. doi: 10.1155/2017/7375818

Bhattacharjee, A., Majumder, S., Das, S., Ghosh, S., Biswas, S., and Majumdar, S. (2016). Leishmania donovani-induced prostaglandin E2 generation is critically dependent on host toll-like receptor 2-cytosolic phospholipase A2 signaling. Infect. Immun. 84, 2963-2973. doi: 10.1128/IAI.00528-16

Borges, M. M., De Andrade, S. G., Pilatti, C. G., do Prado Júnior, J. C., and Kloetzel, J. K. (1992). Macrophage activation and histopathological findings in Calomys callosus and swiss mice infected with several strains of Trypanosoma cruzi. Mem. Inst. Oswaldo Cruz 87, 493-502. doi: 10.1590/S0074-02761992000400006

Bradford, M. M. (1976). A rapid and sensitive method for the quantitation of microgram quantities of protein utilizing the principle of protein-dye binding. Anal. Biochem. 72, 248-254. doi: 10.1016/0003-2697(76)90527-3

Carvalho de Freitas, R., Lonien, S. C. H., Malvezi, A. D., Silveira, G. F., Wowk, P. F., da Silva, R. V., et al. (2017). Trypanosoma cruzi: inhibition of infection of human monocytes by aspirin. Exp. Parasitol. 182, 26-33. doi: 10.1016/j.exppara. 2017.09.019

Castellsague, J., Riera-Guardia, N., Calingaert, B., Varas-Lorenzo, C., FourrierReglat, A., Nicotra, F., et al. (2012). Individual NSAIDs and upper gastrointestinal complications: a systematic review and meta-analysis of observational studies (the SOS project). Drug Saf. 35, 1127-1146. doi: 10.2165/ 11633470-000000000-00000

Castro, A. S., Alves, C. M. O. S., Angeloni, M. B., Gomes, A. O., Barbosa, B. F., Franco, P. S., et al. (2013). Trophoblast cells are able to regulate monocyte activity to control Toxoplasma gondii infection. Placenta 34, 240-247. doi: 10.1016/j.placenta.2012.12.006

Castro-Filice, L. S., Barbosa, B. F., Angeloni, M. B., Silva, N. M., Gomes, A. O., Alves, C. M. O. S., et al. (2014). Azithromycin is able to control Toxoplasma gondii infection in human villous explants. J. Transl. Med. 12:132. doi: 10.1186/ 1479-5876-12-132
Costa, I. N., Angeloni, M. B., Santana, L. A., Barbosa, B. F., Silva, M. C., Rodrigues, A. A., et al. (2009). Azithromycin inhibits vertical transmission of Toxoplasma gondii in Calomys callosus (Rodentia: Cricetidae). Placenta 30, 884-890. doi: 10.1016/j.placenta.2009.08.002

Dong, R., and Zheng, S. (2015). Interleukin-8: a critical chemokine in biliary atresia. J. Gastroenterol. Hepatol. 30, 970-976. doi: 10.1111/jgh.12900

Dubey, J. P. (2010). Toxoplasmosis of Animals and Humans. Boca Raton, FL: CRC Press.

Dubey, J. P., Lago, E. G., Gennari, S. M., Su, C., and Jones, J. L. (2012). Toxoplasmosis in humans and animals in Brazil: high prevalence, high burden of disease, and epidemiology. Parasitology 139, 1375-1424. doi: 10.1017/ S0031182012000765

Fanelli, A., Ghisi, D., Aprile, P. L., and Lapi, F. (2017). Cardiovascular and cerebrovascular risk with nonsteroidal anti-inflammatory drugs and cyclooxygenase 2 inhibitors: latest evidence and clinical implications. Ther. Adv. Drug Saf. 8, 173-182. doi: 10.1177/2042098617690485

Favoreto-Júnior, S., Ferro, E. A. V., Clemente, D., Silva, D. A. O., and Mineo, J. R. (1998). Experimental infection of Calomys callosus (Rodentia, Cricetidae) by Toxoplasma gondii. Mem. Inst. Oswaldo Cruz 93, 103-107. doi: 10.1590/S007402761998000100018

Ferro, E. A. V., Mineo, J. R., Ietta, F., Bechi, N., Romagnoli, R., Silva, D. A. O., et al. (2008). Macrophage migration inhibitory factor is upregulated in human firsttrimester placenta stimulated by soluble antigen of Toxoplasma gondii, resulting in increased monocyte adhesion on villous explants. Am. J. Pathol. 172, 50-58. doi: 10.2353/ajpath.2008.070432

Ferro, E. A. V., Silva, D. A. O., Bevilacqua, E., and Mineo, J. R. (2002). Effect of Toxoplasma gondii infection kinetics on trophoblast cell population in Calomys callosus, a model of congenital toxoplasmosis. Infect. Immun. 70, 7089-7094. doi: 10.1128/IAI.70.12.7089-7094.2002

Flores, M., Saavedra, R., Bautista, R., Viedma, R., Tenorio, E. P., Leng, L., et al. (2008). Macrophage migration inhibitory factor (MIF) is critical for the host resistance against Toxoplasma gondii. FASEB J. 22, 3661-3671. doi: 10.1096/fj. 08-111666

Foroutan-Rad, M., Majidiani, H., Dalvand, S., Daryani, A., Kooti, W., Saki, J., et al. (2016). Toxoplasmosis in blood donors: a systematic review and meta-analysis. Transfus. Med. Rev. 30, 116-122. doi: 10.1016/j.tmrv.2016.03.002

Frade, A. F., Oliveira, L. C., Costa, D. L., Costa, C. H. N., Aquino, D., Weyenbergh, J. V., et al. (2011). TGFB1 and IL8 gene polymorphisms and susceptibility to visceral leishmaniasis. Infect. Genet. Evol. 11, 912-916. doi: 10.1016/j.meegid. 2011.02.014

Franco, P. S., Gomes, A. O., Barbosa, B. F., Angeloni, M. B., Silva, N. M., Teixeira-Carvalho, A., et al. (2011). Azithromycin and spiramycin induce anti-inflammatory response in human trophoblastic (BeWo) cells infected by Toxoplasma gondii but are able to control infection. Placenta 32, 838-844. doi: 10.1016/j.placenta.2011.08.012

Franco, P. S., Ribeiro, M., Lopes-Maria, J. B., Costa, L. F., Silva, D. A. O., Barbosa, B. F., et al. (2014). Experimental infection of Calomys callosus with atypical strains of Toxoplasma gondii shows gender differences in severity of infection. Parasitol. Res. 113, 2655-2664. doi: 10.1007/s00436-014-3920-y

Franco, P. S., Silva, N. M., Barbosa, B. F., Gomes, A. O., Ietta, F., Shwab, E. K., et al. (2015). Calomys callosus chronically infected by Toxoplasma gondii clonal type II strain and reinfected by Brazilian strains is not able to prevent vertical transmission. Front. Microbiol. 6:181. doi: 10.3389/fmicb.2015.00181

Gazzinelli, R. T., Wysocka, M., Hayashi, S., Denkers, E. Y., Hieny, S., Caspar, P., et al. (1994). Parasite-induced IL12 stimulates early IFN gamma synthesis and resistance during acute infection with Toxoplasma gondii. J. Immunol. 153, 2533-2543.

Gomes, A. F., Magalhães, K. G., Rodrigues, R. M., de Carvalho, L., Molinaro, R., Bozza, P. T., et al. (2014). Toxoplasma gondii-skeletal muscle cells interaction increases lipid droplet biogenesis and positively modulates the production of IL-12, IFN-g and PGE2. Parasit. Vectors 7:47. doi: 10.1186/1756-3305-7-47

Gomes, A. O., Barbosa, B. F., Franco, P. S., Ribeiro, M., Silva, R. J., Gois, P. S. G., et al. (2018). Macrophage migration inhibitory factor (MIF) prevents maternal death, but contributes to poor fetal outcome during congenital toxoplasmosis. Front. Microbiol. 9:906. doi: 10.3389/fmicb.2018.00906

Gomes, A. O., Silva, D. A. O., Silva, N. M., Barbosa, B. F., Franco, P. S., Angeloni, M. B., et al. (2011). Effect of macrophage migration inhibitory factor (MIF) in human placental explants infected with Toxoplasma gondii depends on 
gestational age. Am. J. Pathol. 178, 2792-27801. doi: 10.1016/j.ajpath.2011. 02.005

Gorfu, G., Cirelli, K. M., Melo, M. B., Mayer-Barber, K., Crown, D., Koller, B. H., et al. (2014). Dual role for inflammasome sensors NLRP1 and NLRP3 in murine resistance to Toxoplasma gondii. mBio 5:e01117-13. doi: 10.1128/mBio. 01117-13

Green, L. C., Wagner, D. A., Glogowski, J., Skipper, P. L., Wishnok, J. S., and Tannenbaum, S. R. (1982). Analysis of nitrate, nitrite, and [15N]nitrate in biological fluids. Anal. Biochem. 126, 131-138. doi: 10.1016/0003-2697(82) 90118-X

Guerrero, N. A., Camacho, M., Vila, L., Íñiguez, M. A., Chillón-Marinas, C., Cuervo, H., et al. (2015). Cyclooxygenase-2 and prostaglandin E2 signaling through prostaglandin receptor EP-2 favor the development of myocarditis during acute Trypanosoma cruzi infection. PLoS Negl. Trop. Dis. 9:e0004025. doi: 10.1371/journal.pntd.0004025

Hernández, M., Wicz, S., and Corral, R. S. (2016). Cardioprotective actions of curcumin on the pathogenic NFAT/COX-2/prostaglandin $\mathrm{E}(2)$ pathway induced during Trypanosoma cruzi infection. Phytomedicine 23, 1392-1400. doi: 10.1016/j.phymed.2016.06.017

Homan, W. L., Vercammen, M., De Braekeleer, J., and Verschueren, H. (2000). Identification of a 200 - to 300 -fold repetitive 529 bp DNA fragment in Toxoplasma gondii, and its use for diagnostic and quantitative PCR. Int. J. Parasitol. 30, 69-75. doi: 10.1016/S0020-7519(99)00170-8

Hou, B., Benson, A., Kuzmich, L., DeFranco, A. L., and Yarovinsky, F. (2011). Critical coordination of innate immune defense against Toxoplasma gondii by dendritic cells responding via their toll-like receptors. Proc. Natl. Acad. Sci. U.S.A. 108, 278-283. doi: 10.1073/pnas.1011549108

Hwang, Y. S., Shin, J. H., Yang, J. P., Jung, B. K., Lee, S. H., and Shin, E. H. (2018). Characteristics of infection immunity regulated by Toxoplasma gondii to maintain chronic infection in the brain. Front. Immunol. 9:158. doi: 10.3389/ fimmu.2018.00158

Kalinski, P. (2012). Regulation of immune responses by prostaglandin E2. J. Immunol. 188, 21-28. doi: 10.4049/jimmunol.1101029

Kelly, M. N., Kolls, J. K., Happel, K., Schwartzman, J. D., Schwarzenberger, P., Combe, C., et al. (2005). Interleukin-17/interleukin-17 receptor-mediated signaling is important for generation of an optimal polymorphonuclear response against Toxoplasma gondii infection. Infect. Immun. 73, 617-621. doi: 10.1128/IAI.73.1.617-621.2005

Kemp, L. E., Yamamoto, M., and Soldati-Favre, D. (2013). Subversion of host cellular functions by the apicomplexan parasites. FEMS Microbiol. Rev. 37, 607-631. doi: 10.1111/1574-6976.12013

Kim, J. Y., Ahn, M. H., Song, H. O., Choi, J. H., Ryu, J. S., Min, D. Y., et al. (2006). Involvement of MAPK activation in chemokine or COX-2 productions by Toxoplasma gondii. Korean J. Parasitol. 44, 197-207. doi: 10.3347/kjp.2006. 44.3.197

Koblansky, A. A., Jankovic, D., Oh, H., Hieny, S., Sungnak, W., Mathur, R., et al. (2013). Recognition of profilin by Toll-like receptor 12 is critical for host resistance to Toxoplasma gondii. Immunity 38, 119-130. doi: 10.1016/j.immuni. 2012.09.016

Laliberté, J., and Carruthers, V. B. (2008). Host cell manipulation by the human pathogen Toxoplasma gondii. Cell. Mol. Life Sci. 65, 1900-1915. doi: 10.1007/ s00018-008-7556-x

Lang, C., Gross, U., and Luder, C. G. (2007). Subversion of innate and adaptive immune responses by Toxoplasma gondii. Parasitol. Res. 100, 191-203. doi: 10.1007/s00436-006-0306-9

Lonien, S. C. H., Malvezi, A. D., Suzukawa, H. T., Yamauchi, L. M., Yamada-Ogatta, S. F., Rizzo, L. V., et al. (2017). Response to Trypanosoma cruzi by human blood cells enriched with dentritic cells is controlled by cyclooxygenase- 2 pathway. Front. Microbiol. 8:2020. doi: 10.3389/fmicb.2017.02020

Lovo-Martins, M. I., Malvezi, A. D., Zanluqui, N. G., Lucchetti, B. F. C., Tatakihara, V. L. H., Mörking, P. A., et al. (2018). Extracellular vesicles shed by Trypanosoma cruzi potentiate infection and elicit lipid body formation and PGE2 production in murine macrophages. Front. Immunol. 9:896. doi: 10.3389/ fimmu.2018.00896

Malvezi, A. D., da Silva, R. V., Panis, C., Yamauchi, L. M., Lovo-Martins, M. I., Zanluqui, N. G., et al. (2014). Aspirin modulates innate inflammatory response and inhibits the entry of Trypanosoma cruzi in mouse peritoneal macrophages. Mediators Inflamm. 2014:580919. doi: 10.1155/2014/ 580919
Martínez-Colón, G. J., and Moore, B. B. (2018). Prostaglandin E2 as a regulator of immunity to pathogens. Pharmacol. Ther. 185, 135-146. doi: 10.1016/j. pharmthera.2017.12.008

Massó, E. L., Patrignani, P., Tacconelli, S., and García Rodríguez, L. A. (2010). Variability among nonsteroidal antiinflammatory drugs in risk of upper gastrointestinal bleeding. Arthritis Rheum. 62, 1592-1601. doi: 10.1002/art. 27412

Michelin, M. A., Silva, J. S., and Cunha, F. Q. (2005). Inducible cyclooxygenase released prostaglandin mediates immunosuppression in acute phase of experimental Trypanosoma cruzi infection. Exp. Parasitol. 111, 71-79. doi: 10. 1016/j.exppara.2005.05.001

Montoya, J. G., and Liesenfeld, O. (2004). Toxoplasmosis. Lancet 363, 1965-1976. doi: 10.1016/s0140-6736(04)16412-x

Moraes, K. C., Diniz, L. F., and Bahia, M. T. (2015). Role of cyclooxygenase-2 in Trypanosoma cruzi survival in the early stages of parasite host-cell interaction. Mem. Inst. Oswaldo Cruz 110, 181-191. doi: 10.1590/0074-02760140311

Mosmann, T. (1983). Rapid colorimetric assay for cellular growth and survival: application to proliferation and cytotoxicity assays. J. Immunol. Methods 65 55-63. doi: 10.1016/0022-1759(83)90303-4

Mota, L. A., Roberto Neto, J., Monteiro, V. G., Lobato, C. S., Oliveira, M. A., Cunha, Md, et al. (2014). Culture of mouse peritoneal macrophages with mouse serum induces lipid bodies that associate with the parasitophorous vacuole and decrease their microbicidal capacity against Toxoplasma gondii. Mem. Inst. Oswaldo Cruz 109, 767-774. doi: 10.1590/0074-0276140119

Nagamatsu, T., and Schust, D. J. (2010). The immunomodulatory roles of macrophages at the maternal-fetal interface. Reprod. Sci. 17, 209-218. doi: $10.1177 / 1933719109349962$

Nam, Y. H., Min, A., Kim, S. H., Lee, Y. A., Kim, K. A., Song, K., et al. (2012). Leukotriene B4 receptors BLT1 and BLT2 are involved in interleukin8 production in human neutrophils induced by Trichomonas vaginalis-derived secretory products. Inflamm. Res. 61, 97-102. doi: 10.1007/s00011-011-0425-3

Nejad, M. R., Sherafat, S. J., Rochani, M., Telkabadi, M., Lahmi, R., and Cheraghipour, K. (2011). The evaluation of interleukin- 8 chemokine in chronic and acute Toxoplasma gondii infection. Gastroenterol. Hepatol. Bed Bench 4, 34-37.

Oda, J. Y., Belém, M. O., Carlos, T. M., Gouveia, R., Luchetti, B. F. C., Moreira, N. M., et al. (2017). Myenteric neuroprotective role of aspirin in acute and chronic experimental infections with Trypanosoma cruzi. Neurogastroenterol. Motil. 29, 1-13. doi: 10.1111/nmo.13102

Oliveira, L. G., Kuehn, C. C., Santos, C. D., Toldo, M. P., and do Prado, J. C. Jr. (2010). Enhanced protection by melatonin and meloxicam combination in experimental infection by Trypanosoma cruzi. Parasit. Immunol. 32, 245-251. doi: 10.1111/j.1365-3024.2009.01185.x

Oliveira-Cardoso, M. F., Moreli, J. B., Gomes, A. O., de Freitas Zanon, C., Silva, A. E., Paulesu, L. R., et al. (2018). Annexin A1 peptide is able to induce an anti-parasitic effect in human placental explants infected by Toxoplasma gondii. Microb. Pathog. 123, 153-161. doi: 10.1016/j.micpath.2018.07.005

Pawlowski, N. A., Kaplan, G., Hamill, A. L., Cohn, Z. A., and Scott, W. A. (1983). Arachidonic acid metabolism by human monocytes. Studies with plateletdepleted cultures. J. Exp. Med. 158, 393-412. doi: 10.1084/jem.158.2.393

Peyron, F., McLeod, R., Ajzenberg, D., Contopoulos-loannidis, D., Kieffer, F., Mandelbrot, L., et al. (2017). Congenital toxoplasmosis in France and the United States: one parasite, two diverging approaches. Plos Negl. Trop. Dis. 11:e0005222. doi: 10.1371/journal.pntd.0005222

Pinge-Filho, P., Tadokoro, C. E., and Abrahamsohn, I. A. (1999). Prostaglandins mediate suppression of lymphocyte proliferation and cytokine synthesis in acute Trypanosoma cruzi infection. Cell Immunol. 193, 90-98. doi: 10.1006/ cimm.1999.1463

Robert-Gangneux, F., and Dardé, M. L. (2012). Epidemiology of and diagnostic strategies for toxoplasmosis. Clin. Microbiol. Rev. 25, 264-296. doi: 10.1128/ CMR.05013-11

Rodrigues, A. A., Clemente, T. M., Dos Santos, M. A., Machado, F. C., Gomes, R. G., Moreira, H. H., et al. (2012). A recombinant protein based on Trypanosoma cruzi P21 enhances phagocytosis. PLoS One 7:e51384. doi: 10.1371/journal. pone.0051384

Sharma, M., Sharma, R., McCarthy, E. T., Savin, V. J., and Srivastava, T. (2017). Hyperfiltration-associated biomechanical forces in glomerular injury and response: potential role for eicosanoids. Prostaglandins Other Lipid Mediat. 132, 59-68. doi: 10.1016/j.prostaglandins.2017.01.003 
Short, S. S., Wang, J., Castle, S. L., Fernandez, G. E., Smiley, N., Zobel, M., et al. (2013). Low doses of celecoxib attenuate gut barrier failure during experimental peritonitis. Lab. Invest. 93, 1265-1275. doi: 10.1038/labinvest. 2013.119

Silva, R. J., Gomes, A. O., Franco, P. S., Pereira, A. S., Milian, I. C. B., Ribeiro, M., et al. (2017). Enrofloxacin and toltrazuril are able to reduce Toxoplasma gondii growth in human BeWo trophoblastic cells and villous explants from human third trimester pregnancy. Front. Cell Infect. Microbiol. 7:340. doi: 10.3389/ fcimb.2017.00340

Sommerville, C., Richardson, J. M., Williams, R. A. M., Mottram, J., Roberts, C. W., Alexander, J., et al. (2013). Biochemical and immunological characterization of Toxoplasma gondii macrophage migration inhibitory factor. J. Biol. Chem. 288, 12733-12741. doi: 10.1074/jbc.M112.419911

Tatakihara, V. L. H., Cecchini, R., Borges, C. L., Malvezi, A. D., Graça-de Souza, V. K., Yamada-Ogatta, S. F., et al. (2008). Effects of cyclooxygenase inhibitors on parasite burden, anemia and oxidative stress in murine Trypanosoma cruzi infection. FEMS Immunol. Med. Microbiol. 52, 47-58. doi: 10.1111/j.1574-695X. 2007.00340.x
Terrazas, C. A., Juarez, I., Terrazas, L. I., Saavedra, R., Calleja, E. A., and Rodriguez-Sosa, M. (2010). Toxoplasma gondii: impaired maturation and pro-inflammatory response of dendritic cells in MIF-deficient mice favors susceptibility to infection. Exp. Parasitol. 126, 348-358. doi: 10.1016/j.exppara. 2010.03.009

Conflict of Interest Statement: The authors declare that the research was conducted in the absence of any commercial or financial relationships that could be construed as a potential conflict of interest.

Copyright @ 2019 Pereira, Silva, Franco, de Oliveira Gomes, Souza, Milian, Ribeiro, Rosini, Guirelli, Ramos, Mineo, Mineo, Silva, Ferro and Barbosa. This is an openaccess article distributed under the terms of the Creative Commons Attribution License (CC BY). The use, distribution or reproduction in other forums is permitted, provided the original author(s) and the copyright owner(s) are credited and that the original publication in this journal is cited, in accordance with accepted academic practice. No use, distribution or reproduction is permitted which does not comply with these terms. 